Review

\title{
Lysosomal Calcium Channels in Autophagy and Cancer
}

\author{
Yi Wu ${ }^{1}$, Peng Huang ${ }^{1, *}$ and Xian-Ping Dong ${ }^{2, *}$ (D) \\ 1 Collaborative Innovation Center for Biomedicine, School of Clinical Medicine, Shanghai University of \\ Medicine and Health Sciences, Shanghai 201318, China; Wuy_20@sumhs.edu.cn \\ 2 Departments of Physiology and Biophysics, Dalhousie University, 5850 College Street, \\ Halifax, NS B3H 4R2, Canada \\ * Correspondence: huangp_15@sumhs.edu.cn (P.H.); xpdong@dal.ca (X.-P.D.)
}

Citation: Wu, Y.; Huang, P.; Dong, X.-P. Lysosomal Calcium Channels in Autophagy and Cancer. Cancers 2021, 13, 1299. https://doi.org/ 10.3390/cancers13061299

Academic Editor:

Vanessa Soto-Cerrato

Received: 8 February 2021

Accepted: 9 March 2021

Published: 15 March 2021

Publisher's Note: MDPI stays neutral with regard to jurisdictional claims in published maps and institutional affiliations.

Copyright: (c) 2021 by the authors. Licensee MDPI, Basel, Switzerland. This article is an open access article distributed under the terms and conditions of the Creative Commons Attribution (CC BY) license (https:// creativecommons.org/licenses/by/ $4.0 /)$.
Simple Summary: Autophagy is a cellular self-eating process that uses lysosome, the waste disposal system of the cell, to degrade and recycle intracellular materials to maintain cellular homeostasis. Defects in autophagy are linked to a variety of pathological states, including cancer. Calcium is an important cellular messenger that regulates the survival of all animal cells. Alterations to calcium homoeostasis are associated with cancer. While it has long been considered as cellular recycling center, the lysosome is now widely known as an intracellular calcium store that regulates autophagy and cancer progression by releasing calcium via some ion channels residing in the lysosomal membrane. In this review, we summarize existing mechanisms of autophagy regulation by lysosomal calcium channels and their implications in cancer development. We hope to guide readers toward a more in-depth understanding of the importance of lysosomal calcium channels in cancer, and potentially facilitate the development of new therapeutics for some cancers.

Abstract: $\mathrm{Ca}^{2+}$ is pivotal intracellular messenger that coordinates multiple cell functions such as fertilization, growth, differentiation, and viability. Intracellular $\mathrm{Ca}^{2+}$ signaling is regulated by both extracellular $\mathrm{Ca}^{2+}$ entry and $\mathrm{Ca}^{2+}$ release from intracellular stores. Apart from working as the cellular recycling center, the lysosome has been increasingly recognized as a significant intracellular $\mathrm{Ca}^{2+}$ store that provides $\mathrm{Ca}^{2+}$ to regulate many cellular processes. The lysosome also talks to other organelles by releasing and taking up $\mathrm{Ca}^{2+}$. In lysosomal $\mathrm{Ca}^{2+}$-dependent processes, autophagy is particularly important, because it has been implicated in many human diseases including cancer. This review will discuss the major components of lysosomal $\mathrm{Ca}^{2+}$ stores and their roles in autophagy and human cancer progression.

Keywords: lysosome; ion channel; calcium; autophagy; cancer

\section{Introduction}

The lysosome is an acidic single-membrane organelle first discovered in 1955 by Christian de Duve while investigating the mechanism of action of insulin [1-3]. It contains more than 60 hydrolytic enzymes (e.g., nucleases, glycosidase, phosphatases, sulfatases, lipases, and proteases), which are active at the luminal acidic environment ( $\mathrm{pH} 4.5-5.0)$ established by the vacuolar-ATPase (V-ATPase) proton pump [4,5]. Since its discovery, the lysosome has mainly been considered to be the center of waste disposal, which digests unwanted macromolecules, damaged and senescent organelles, microbes, and other particles delivered via endocytosis, autophagy, and phagocytosis [4,6-8]. Once degraded, some breakdown products such as free fatty acids, amino acid, monosaccharides and nucleotides are transported back to the cytosol via specific exporters in the lysosome membrane for reutilization in anabolic processes $[9,10]$. Lysosomes also contain more than 60 membrane proteins that are implicated in the maintenance of the lumen homeostasis, especially ionic homeostasis and membrane potential, in the control of molecular export across the lysosomal membrane, and in lysosomal membrane trafficking (i.e., fusion and fission). The 
functions of lysosomes in material degradation, catabolite export, or trafficking are key to maintaining cellular homeostasis, the perturbations of which often lead to lysosomal storage diseases (LSDs) [11].

Recent studies have shown that the lysosome is not only the terminal degradative compartment, but also a multifunctional signaling hub that integrates the cell's responses to nutrient status, growth factors, and hormones. Noticeably, in order to adapt to changes in cellular environment, the lysosome has a nutrient-sensing mechanism involving mammalian/mechanistic target of rapamycin complex 1 (mTORC1) and transcription factor EB (TFEB) [12-14]. mTORC1 is capable of sensing a myriad of nutrient and energy cues, phosphorylating numerous cell growth-related substrates including TFEB, and thus governing the balance between catabolic and anabolic metabolic pathways in the cell [15] TFEB can bind to a palindromic $10 \mathrm{bp}$ nucleotide motif, named the coordinated lysosomal expression, and regulation (CLEAR) element, and activate the transcription of many genes encoding lysosomal proteins and autophagy-related proteins [16,17]. Under nutrient sufficient conditions, TFEB is sequestered away from the nucleus due to being phosphorylated by mTORC1. Conversely, under starvation, TFEB becomes dephosphorylated due to a reduction in mTORC1 and an activation of calcineurin $(\mathrm{CaN}), \mathrm{a} \mathrm{Ca}^{2+}$ and calmodulin (CaM) dependent serine/threonine protein phosphatase, and translocates to the nucleus to promote the transcription of the CLEAR element, which subsequently promotes autophagylysosome pathway as well as exocytosis and phagocytosis [8,18-20].

Autophagy is an evolutionarily conserved cellular degradative process that is induced by nutrient and energy starvation. It is a fundamental cellular program for cells to maintain intracellular energy and nutrient homeostasis and to protect cells against stress. During autophagy, intracellular components such as macromolecules and unwanted organelles are engulfed in autophagosomes that then fuse with lysosomes to form autolysosomes for degradation [21]. Lysosomal $\mathrm{Ca}^{2+}$ plays a key role in autophagy. For example, Transient Receptor Potential Mucolipin 1 (TRPML1, encoded by MCOLN1 gene), an important $\mathrm{Ca}^{2+}$ channel in the lysosome, governs autophagy through regulating both mTORC1 [22,23] and TFEB [24,25]. Because autophagy has an essential role in cellular homeostasis, it is implicated in various physiological processes and human diseases. Among them, the roles of autophagy in cancer have been extensively studied. Thus, in this review we focus on the role of lysosomal $\mathrm{Ca}^{2+}$ channels in autophagy and cancer.

\section{Lysosomal $\mathrm{Ca}^{2+}$ Homeostasis}

The lysosome is a significant intracellular $\mathrm{Ca}^{2+}$ store, which coordinates cellular adaptive responses [12,15,26-30]. In the early 1990s, nicotinic acid adenine dinucleotide phosphate (NAADP) was discovered to be a potent mobilizer of $\mathrm{Ca}^{2+}$ from stores separated from those sensitive to inositol 1,4,5-trisphosphate (IP3) and cyclic ADP-ribose (cADPR) [31]. It was later shown that the NAADP-sensitive $\mathrm{Ca}^{2+}$ store is the functional equivalent of the lysosomal system, suggesting the lysosome may function as a $\mathrm{Ca}^{2+}$ store [32]. Indeed, in the same time, the lysosomal $\mathrm{Ca}^{2+}$ concentration was estimated to be $\sim 0.5 \mathrm{mM}$, approximately 5000 -fold higher than the cytosolic $\mathrm{Ca}^{2+}$ concentration ( $100 \mathrm{nM}$ ) [33-35]. This $\mathrm{Ca}^{2+}$ gradient across the lysosomal membrane is thought to be established by an unidentified $\mathrm{Ca}^{2+} / \mathrm{H}^{+}$exchanger or $\mathrm{Ca}^{2+}$ transporter [36,37]. Multiple $\mathrm{Ca}^{2+}$ sensors including CaM, apoptosis linked gene 2 (ALG-2), and synaptotagmin 7 (Syt 7) associated with lysosomes have also been identified [22,33,38-41]. This further increases the diversity of lysosomal $\mathrm{Ca}^{2+}$-dependent processes. Recently, several groups have made new discoveries elucidating the molecular machinery underlying lysosomal $\mathrm{Ca}^{2+}$ release, $\mathrm{Ca}^{2+}$ signaling, and $\mathrm{Ca}^{2+}$ uptake (Figure 1 ). 


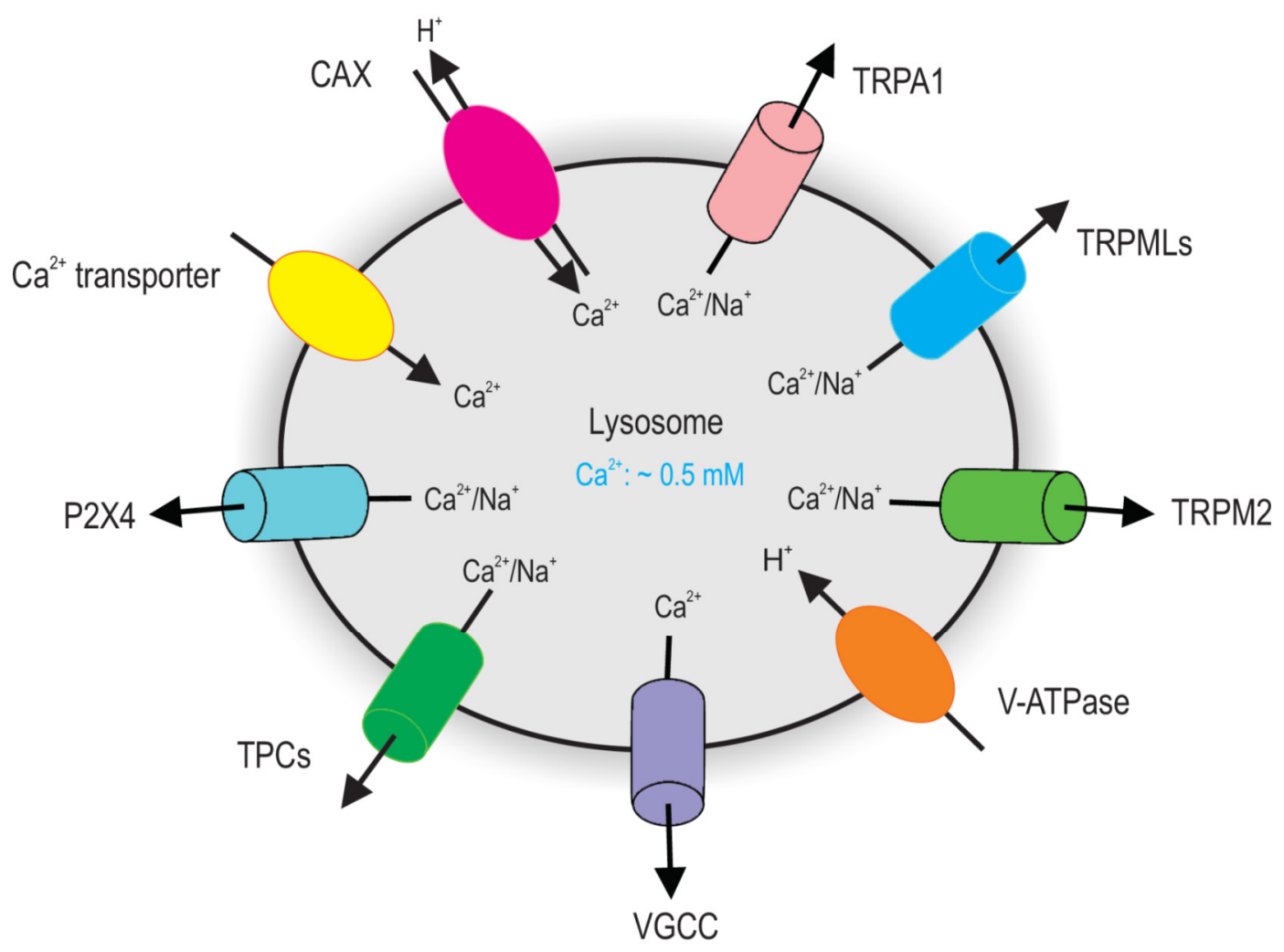

Figure 1. Major $\mathrm{Ca}^{2+}$ releasing channels and transporters on lysosomes. TRPML channels and TPC channels are major groups of $\mathrm{Ca}^{2+}$ channels on lysosomes that have been definitely defined by endolysosome-patch-clamp. Given the topology of the TRPML proteins at the endolysosomal membrane and the electrical properties of the endolysosome, TRPML opening leads to $\mathrm{Ca}^{2+}$ and $\mathrm{Na}^{+}$release from the endolysosome to the cytosol. Activation of TPCs release lysosomal $\mathrm{Na}^{+}$and $\mathrm{Ca}^{2+}$. Lysosomes accumulate $\mathrm{Ca}^{2+}$ using a putative $\mathrm{Ca}^{2+}$ Transporter or $\mathrm{Ca}^{2+} / \mathrm{H}^{+}$exchanger (CAX).

\subsection{Lysosomal $\mathrm{Ca}^{2+}$ Release}

Lysosomal $\mathrm{Ca}^{2+}$ is mainly released through TRPML1, which belongs to the TRPML channel family including TRPML1, TRPML2, and TRPML3. TRPML proteins form tetramers, and each pore-forming subunit contains six transmembrane domains (TM1-TM6 or S1-S6) (Figure 2A-C). While TRPML1 is predominantly localized on the late endosomes and the lysosomes, TRPML2 and TRPML3 are primarily on the recycling endosomes and the early endosomes, respectively. In contrast to TRPML1, which is ubiquitously expressed in all tissues, TRPML2 and TRPML3 expressed in specific organs [42].

TRPML1 is a $\mathrm{Ca}^{2+}$-permeable, non-selective cation channel that can be activated by phosphatidylinositol 3,5-bisphosphate [PI(3,5)P2] [43,44] but inhibited by mTORC1 [22,45]. Normally under nutrient rich conditions, mTORC1 phosphorylates and inhibits TRPML1. During starvation, a reduction in mTORC1 activates TRPML1, stimulating the TFEBdependent autophagy pathway, helping the cell survive extreme conditions [22]. TRPML1 is also regulated by some compounds, including mucolipin-specific synthetic agonists (ML-SAs) [46,47] and synthetic inhibitors ML-SIs [45] (Table 1). Physiologically, TRPML1 plays an important role in membrane trafficking, autophagy, lysosomal biogenesis, and lysosomal exocytosis [42,48]. Deficient TRPML1 causes type IV mucolipidosis (ML-IV), an autosomal recessive lysosomal storage disorder showing psychomotor retardation. Impaired TRPML1 has also been implicated in several other LSDs [49]. 
A

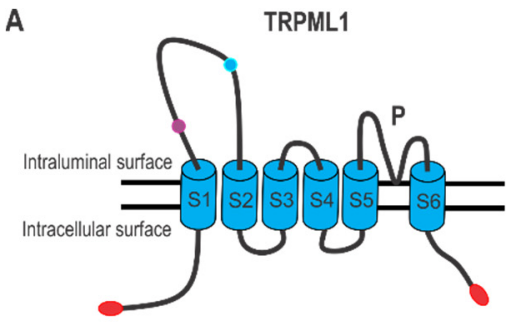

B

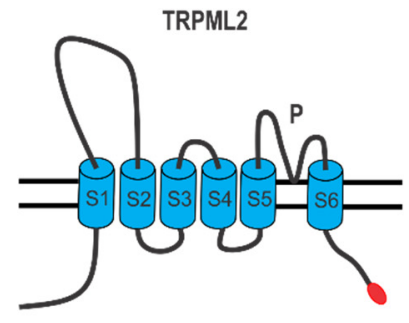

C

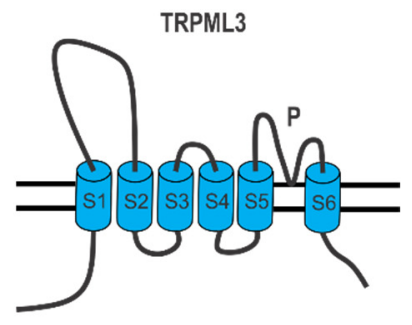

D

TPC1

E

TPC2
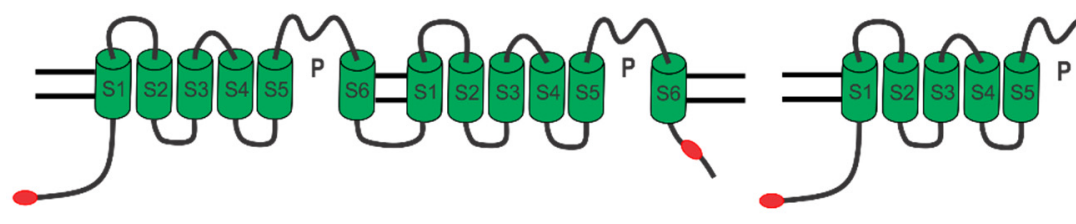

te

- $\quad$ Serine lipase motif

Figure 2. Structure of TRPML channels and TPC channels. (A-C) TRPML channels have a six membrane-spanning region (S1-S6), a putative pore region (P), and a large luminal loop between S1 and S2. Dileucine motifs in TRPML1 and TRPML2 at their C-and/or N-termini determine their intracellular endolysosomal localization. The endolysosomal localization of TRPML3 is determined by its heteromultimerization with other TRPMLs. Functional TRPMLs are tetramers. (D,E) TPC Channels are comprised two repeated domains, with each of them containing six transmembrane helices (S1-S6) and a pore loop (P) domain. TPC1 has two di-leucine motifs, while TPC2 has only one.

Table 1. Agonists and antagonists of TRPMLs and TPCs.

\begin{tabular}{|c|c|c|}
\hline Lysosomal $\mathrm{Ca}^{2+}$ Channels & Agonists & Antagonists \\
\hline TRPML1 & $\begin{array}{c}\text { ML-SAs }[46,47,50-52] \\
\text { SF-51 [50] } \\
\text { MK6-83 [53] }\end{array}$ & ML-SIs $[45,47,51,52,54,55]$ \\
\hline TRPML2 & $\begin{array}{c}\text { ML-SAs } \\
\text { ML2-SA1 [56] }\end{array}$ & ML-SIs \\
\hline TRPML3 & $\begin{array}{l}\text { ML-SAs } \\
\text { SFs [50] }\end{array}$ & ML-SIs \\
\hline TPC1 & LyNa-VA and LyNA [57] & $\begin{array}{c}\text { Tetrandrine }[58,59] \\
\text { Ned-19 }[60]\end{array}$ \\
\hline TPC2 & $\begin{array}{l}\text { TPC2-A1-N and TPC2-A1-P [61] } \\
\text { LyNa-VA and LyNA [57] }\end{array}$ & $\begin{array}{l}\text { Tetrandrine }[58,59] \\
\text { Ned-19 [60] }\end{array}$ \\
\hline
\end{tabular}

Two-pore channels, including TPC1 and TPC2 in human, are widely expressed in the endolysosomal system. They form a homodimer, with each pore-forming subunit comprising two repeats of six-transmembrane domains (Figure 2D,E). Functional TPC1/2 are dimetric non-selective $\mathrm{Na}^{+} / \mathrm{Ca}^{2+}$ channels that can be evoked by both NAADP and PI(3,5)P2 [43,57,62-64]. While TPC1 is expressed in both the early endosomes and the lysosomes, TPC2 is predominantly present on the lysosomal membranes [65]. TPCs are normally suppressed by intracellular ATP through mTORC1 kinase. Starvation and pharmacological inhibition of mTORC1 leads to TPC-dependent $\mathrm{Ca}^{2+}$ release to regulate autophagy [65,66] (Figure 3). Pharmacologically, both TPC1 and TPC2 are activated by a group of antidepressants LyNa-VAs and LyNA (i.e., Riluzole) [57]. TPC2 is also activated 
by two lipophilic and structurally distinct compounds TPC2-A1-N and TPC2-A1-P [61]. On the other hand, a structural analog of NAADP Ned 19 [60] and a bis-benzylisoquinoline alkaloid Tetrandrine [58,59] have been suggested to inhibit both TPC1 and TPC2, although definitive evidence supporting this claim is still lacking (Table 1).

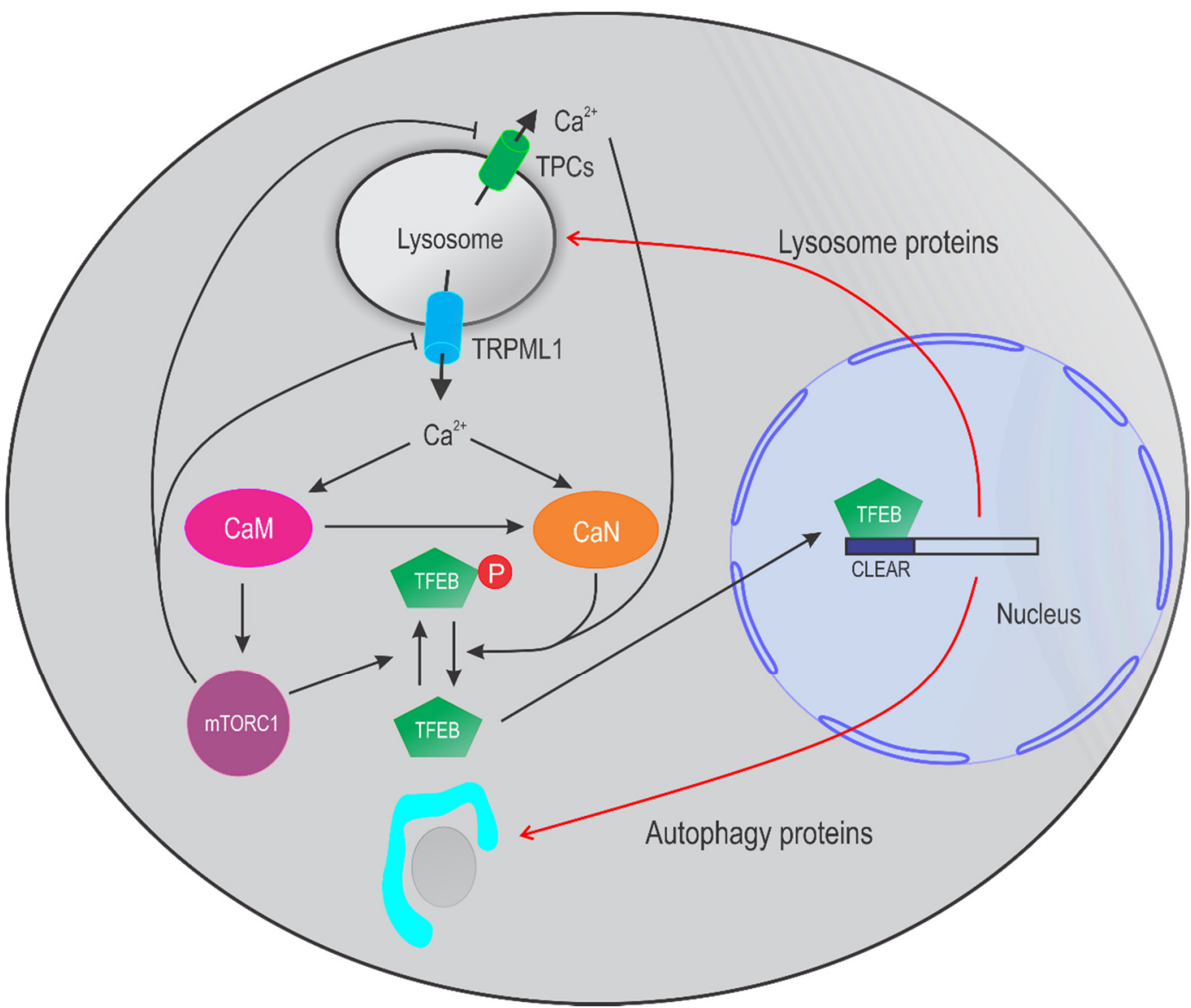

Figure 3. Lysosomal $\mathrm{Ca}^{2+}$ signaling pathways that regulate autophagy and lysosome biogenesis. In nutrient rich condition, mTORC1 phosphorylates and inhibits TRPML1, TPC2, and TFEB. Nutrient starvation activates TRPML1 due to a reduction of mTORC1 activity. $\mathrm{Ca}^{2+}$ released via TRPML1 activates calmodulin (CaM). On the one hand, activated CaM induces calcineurin (CaN) activation and subsequent TFEB dephosphorylation. Dephosphorylated TFEB translocates to nucleus to activate the CLEAR genes to promote lysosomal biogenesis and autophagy. On the other hand, CaM stimulates mTORC1 for basal protein synthesis, preventing cell death. Therefore, TRPML1/CaM coordinates CaN and mTORC1 to maintain homeostasis during nutrient starvation. TPCs may also participate in TFEB regulation in some cell types.

$\mathrm{P} 2 \mathrm{X} 4$ is a trimeric 2 helix-transmembrane channel that belongs to the ionotropic P2X-family ATP receptors. P2X4 is gated by intraluminal ATP to mediate $\mathrm{Ca}^{2+}$ release from the lysosome. P2X4 activity is also regulated by lysosomal $\mathrm{pH}$ with acidic luminal $\mathrm{pH}$ suppressing its activity $[67,68]$. Activation of P2X4-dependent $\mathrm{Ca}^{2+}$ release has been reported to promote lysosome fusion in a CaM-dependent manner [38].

Several other $\mathrm{Ca}^{2+}$ channels have been suggested to be expressed in the lysosome as well. These include transient receptor potential ankyrin 1 (TRPA1), a $\mathrm{Ca}^{2+}$-permeable non-selective cation channel found in somatosensory neurons [69]; transient receptor potential melastatin 2 (TRPM2), a $\mathrm{Ca}^{2+}$ permeable non-selective cation channel gated by ADP-ribose and $\mathrm{Ca}^{2+}[70]$; snd P/Q-type voltage gated $\mathrm{Ca}^{2+}$ channels (VGCCs), $\mathrm{Ca}^{2+}$ channels regulating the fusion of autophagosomes with lysosomes in neurons [64]. However, their functions in lysosomes have not been determined by direct lysosome-patch-clamp recording. Currently, the major $\mathrm{Ca}^{2+}$ channels involved in the autophagy are TRPMLs and TPCs channels. 


\subsection{Lysosomal $\mathrm{Ca}^{2+}$ Store Refilling}

Due to the storage capacity, the lysosome needs to be refilled with $\mathrm{Ca}^{2+}$ after release. The refilling of lysosomal $\mathrm{Ca}^{2+}$ store seems to be dependent on the lysosomal $\mathrm{H}^{+}$ (Figure 1), because (1) elevation of lysosomal $\mathrm{pH}$ and inhibition of V-ATPase deplete $\mathrm{Ca}^{2+}$ store $[33,36,46] ;$; $2 \mathrm{Ca}^{2+}$ store is maintained through the $\mathrm{Ca}^{2+}-\mathrm{H}^{+}$exchanger (CAX) in the vacuoles of yeast and plant, which is from some respects the equivalent of lysosomes in animal cells [36]. Therefore, it is conceivable that $\mathrm{Ca}^{2+} / \mathrm{H}^{+}$exchanger may take part in the $\mathrm{Ca}^{2+}$ uptake in the lysosome $[33,36]$. However, in addition to triggering lysosomal $\mathrm{Ca}^{2+}$ release, manipulation of lysosomal $\mathrm{pH}$ may affect lysosomal $\mathrm{Ca}^{2+}$ concentration or its measurement. For example, because the lysosome contains substantial $\mathrm{Ca}^{2+}$ buffers [71] that binds $\mathrm{Ca}^{2+}$ much better at neutral $\mathrm{pH}$ [72], increasing lysosomal $\mathrm{pH}$ may reduce lysosomal free $\mathrm{Ca}^{2+}$ without necessarily triggering lysosomal $\mathrm{Ca}^{2+}$ release and affecting total $\mathrm{Ca}^{2+}$ content [72]. Lysosomal $\mathrm{pH}$ may also affect the chromophore fluorescence and $\mathrm{Ca}^{2+}$ binding affinity $\left(K_{\mathrm{d}}\right)$ of $\mathrm{Ca}^{2+}$ dyes sequestered in the lumen, because $K_{\mathrm{d}}$ drops significantly when lysosomal $\mathrm{pH}$ increases [71]. Additionally, lysosomal $\mathrm{pH}$ elevation may indirectly affect lysosomal $\mathrm{Ca}^{2+}$ homeostasis by regulating membrane fusion and fission between compartments containing different amounts of $\mathrm{Ca}^{2+}, \mathrm{H}^{+}$, and their buffers [36,73]. To study lysosomal $\mathrm{Ca}^{2+}$ refilling under more physiological conditions, Garrity et al. [73] have adopted a lysosome-targeted GCaMP (fused to the cytosolic N-terminus of TRPML1) [46] to directly monitor the real-time changes in lysosomal $\mathrm{Ca}^{2+}$. They reported that inhibition of the $\mathrm{H}^{+}$gradient in the lysosome, for example, by V-ATPase inhibitors, did not affect $\mathrm{Ca}^{2+}$ refilling. Therefore, the identity of the channel or exchanger mediating lysosomal $\mathrm{Ca}^{2+}$ uptake is still unclear $[33,36]$. In line with this, it has been previously suggested that $\mathrm{Ca}^{2+}$ uptake into lysosomes is mediated by a low-affinity $\mathrm{Ca}^{2+}$ transporter [74]. Very recently, the P5 ATPase ATP13A2 was suggested to mediate lysosomal $\mathrm{Ca}^{2+}$ entry [37]. However, whether ATP13A2 transport $\mathrm{Ca}^{2+}$ into lysosomes is regulated by $\mathrm{H}^{+}$gradient across the lysosomal membrane remains unclear.

$\mathrm{ER} \mathrm{Ca}^{2+}$ has been suggested to play an important role in $\mathrm{Ca}^{2+}$ refilling [73]. Moreover, it is IP3 receptors (IP3Rs) rather than ryanodine receptors (RyRs) that are involved in this process. Thus, a three step model has been proposed based on the structurally intimate localization of the ER and the lysosome [75,76]: (1) refilling stimulated by increased perilysosomal $\mathrm{Ca}^{2+}$ and/or decreased lysosomal $\mathrm{Ca}^{2+}$; (2) formation of ER-lysosome membrane contact sites (MCS) [73,77-79]; and (3) $\mathrm{Ca}^{2+}$ transport from the ER to the lysosome through functional ER-lysosome membrane contact sites.

\subsection{Crosstalk between Lysosomes and Other $\mathrm{Ca}^{2+}$ Stores}

By releasing and taking up $\mathrm{Ca}^{2+}$, the lysosomes, along with the ER, modulate cytosolic $\mathrm{Ca}^{2+}$ signaling events. On the one hand, lysosomal $\mathrm{Ca}^{2+}$ release can induce $\mathrm{Ca}^{2+}$ release from the ER using a mechanism similar to the $\mathrm{Ca}^{2+}$ induced $\mathrm{Ca}^{2+}$ release (CICR). This further causes $\mathrm{Ca}^{2+}$ entry from the extracellular space due to the depletion of the ER $\mathrm{Ca}^{2+}$ store, evoking global Ca ${ }^{2+}$ signals in human cells [80]. Both TRPML1 [81] and TPC2 [82-84]-mediated $\mathrm{Ca}^{2+}$ release are involved in this process. On the other hand, increasing evidence has suggested that, when lysosomal $\mathrm{Ca}^{2+}$ store is depleted, $\mathrm{Ca}^{2+}$ in the ER is transported to the lysosome via IP3R to refill the lysosome with $\mathrm{Ca}^{2+}[73,85]$. The bidirectional $\mathrm{Ca}^{2+}$ signaling between the lysosome and the ER [86] has also been supported by the identification of the ER-lysosome contact sites [77,87] (Figure 4). In addition, new evidence suggests that the lysosome may also act as a $\mathrm{Ca}^{2+}$ buffer to shape extracellular $\mathrm{Ca}^{2+}$ entry and the ER Ca ${ }^{2+}$ re-uptake [85]. 


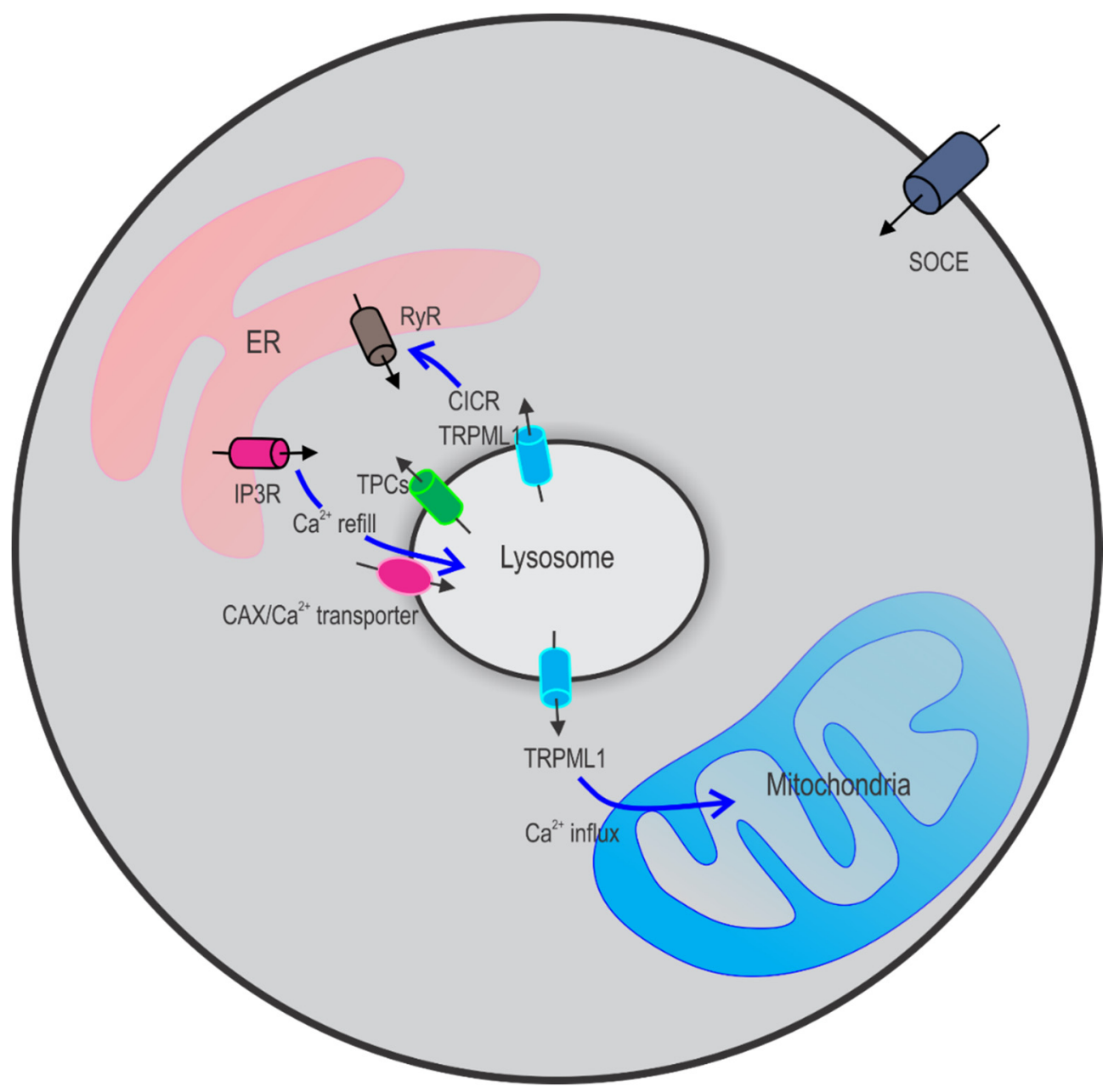

Figure 4. Interaction between lysosomes and the endoplasmic reticulum (ER) and mitochondria. On the one hand, lysosomal $\mathrm{Ca}^{2+}$ release through ion channels such as TRPML1 and TPC2 triggers $\mathrm{Ca}^{2+}$ release from the ER $\mathrm{Ca}^{2+}$ stores. On the other hand, when lysosomal $\mathrm{Ca}^{2+}$ store is depleted, $\mathrm{Ca}^{2+}$ released via IP3R from ER refills lysosomes. Lysosomal TRPML1 also promotes $\mathrm{Ca}^{2+}$ transfer from lysosomes to mitochondria. CICR: calcium induced calcium release; SOCE: store operated calcium entry.

Interorganellular contacts between mitochondria and lysosomes have also been suggested recently [88-90]. Using high-resolution microscopy, Wong et al. [88,89] identified a dynamic formation of contact sites between mitochondria and lysosomes that were regulated by Rab7, a small GTPase associated with lysosomes. These contact sites allow bidirectional crosstalk between mitochondria and lysosomes and regulate the organelle network dynamics, such as mitochondrial fission. By high spatial and temporal resolution live-cell microscopy, they further suggested a role of the mitochondria-lysosome contact in regulating mitochondrial $\mathrm{Ca}^{2+}$ dynamics by lysosomal TRPML1, i.e., in the presence of mitochondria-lysosome contact, lysosomal $\mathrm{Ca}^{2+}$ release through TRPML1 promotes $\mathrm{Ca}^{2+}$ transfer to mitochondria [90] (Figure 4). Taken together, emerging evidence suggests that the lysosome may regulate intracellular $\mathrm{Ca}^{2+}$ signaling by buffering ER $\mathrm{Ca}^{2+}$ release and uptake, mitochondrial $\mathrm{Ca}^{2+}$ release uptake, and extracellular $\mathrm{Ca}^{2+}$ influx.

\section{Autophagy}

Autophagy is a self-eating process that is important for balancing sources of energy at critical times in development and in response to nutrient stress. The cell uses an autophagy pathway to degrade and recycle cytoplasmic constituents such as protein aggregates, lipids, and complete organelles for cell survival. It is especially important 
in postmitotic cells, such as muscles and neurons, where accumulation of aggregated proteins and damaged organelles often results in cell death [91-93]. Indeed, suppression of autophagy causes compromised neuron and muscle differentiation [94-96] as well as neurodegeneration [91-93] and myofiber degeneration [97,98].

In most cells, autophagy is kept at a low level under nutrient rich condition. However, stressful conditions, such as nutritional deprivation, oxidative stress, $\mathrm{Ca}^{2+}$ overload, pathogen infection, and other diseases, activate autophagy. By upregulating autophagy under such conditions, cells degrade macromolecules into their building blocks for reutilization, thereby adapting to extreme conditions and maintaining cellular homeostasis.

There are three types of autophagy: macroautophagy [99,100], microautophagy [99,101], and chaperone-mediated autophagy (CMA) [102,103]. Macroautophagy is the most common form of autophagy, which is characterized by the formation of a typical doublemembrane cistern (so called phagophore) that extends and engulfs part of the cytoplasm to form a whole vesicle (so called autophagosome). The autophagosome ultimately fuses with a lysosome to form an autolysosome [104-106]. In this review, we focus on macroautophagy (hereafter referred to as autophagy).

The process of autophagy is controlled by multiple complexes of proteins encoded by evolutionarily conserved, autophagy-related (ATG) genes, which were originally identified in yeast. The products of these ATG genes, together with other autophagy-related factors, regulate autophagosome formation, tethering, and fusion with lysosomes [107-110]. Autophagy is also regulated by some non-ATG proteins. For example, in the presence of nutrients, ATG1/ULK1 is phosphorylated by mTORC1 [111], thereby inhibiting autophagy initiation [112]. mTORC1 can also phosphorylate and inactivate TFEB, repressing autophagy $[13,113]$. In the absence of nutrients, TRPML1-metiated lysosomal $\mathrm{Ca}^{2+}$ release activates $\mathrm{CaN}$, which further causes TFEB dephosphorylation and nuclear translocation, thereby promoting autophagy [25].

Studies of mammalian systems have highlighted many important roles of autophagy in health and diseases including cell growth [114] and differentiation [96], LSDs [49,115], neurodegenerative diseases [92,93], bacterial infections [116], and cancers [117,118].

\section{Lysosomal $\mathrm{Ca}^{2+}$ in Autophagy}

\subsection{TRPML Channels in Autophagy}

It is widely accepted that $\mathrm{Ca}^{2+}$ can regulate autophagy, while mechanisms differ depending on the conditions. The interplay between lysosomal $\mathrm{Ca}^{2+}$ signal and autophagy has also been reported. In line with this, several lysosomal $\mathrm{Ca}^{2+}$-permeable channels have been suggested to regulate autophagy [119-121].

As a key $\mathrm{Ca}^{2+}$ release channel in the lysosomal membrane, TRPML1 deficiency leads to defective autophagy including accumulation of autophagosomes and aggregation of p62 proteins [122-125]. Growing evidence suggests that TRPML1 plays multifaceted roles in autophagy. Under normal conditions, mTORC1 phosphorylates and inhibits both TRPML1 and TFEB. Cellular stress activates TRPML1 due to mTORC1 inhibition. This further activates downstream pathways including (1) CaM/CaMKK $\beta$ / AMPK-dependent autophagosome formation [126], (2) ALG-2-dependent lysosome centripetal movement to promote autophagosome-lysosome fusion [45], (3) proteolytic degradation in autolysosomes [127], (4) Syt7-dependent lysosomal exocytosis to remove cellular garbage [45,128], (5) CaM-dependent mTORC1 reactivation to prevent cell death by increasing protein synthesis and promote lysosome reformation [22,23], and (6) CaN/TFEB activation to continuously supply lysosome and autophagy proteins [24,25,47] (Figure 3). Because TRPML1 is also a target of TFEB, a positive feedback is established to largely potentiate autophagy during stress [24,25]. Thus, TRPML1 is involved in several steps of autophagy including autophagosome formation, autophagosome maturation, autolysosome degradation, and autophagic lysosome reformation.

In addition to TRPML1, TRPML3 also takes part in autophagy regulation. TRPML3 has been found in the plasma membrane and multiple intracellular compartments, in- 
cluding autophagosomes, early endosomes, late endosomes, and lysosomes. The multiple compartmental localization of TRPML3 suggests that TRPML3 is dynamically expressed in different compartments and plays a role in membrane trafficking. Indeed, TRPML3 is accumulated in the plasma membrane upon inhibition of endocytosis and is recruited to autophagosomes upon induction of autophagy, thereby regulating endocytosis and autophagy [129]. Specifically for autophagy, TRPML3 overexpression increases while its knock-down or expression of the channel-dead dominant negative TRPML3 reduces autophagy [129]. Mechanistically, emerging evidence suggests that palmitoylation at its C-terminal region is required for TRPML3's function in autophagosome formation, potentially by controlling its trafficking to autophagic structures [130], where TRPML3 may promote autophagosome maturation by providing $\mathrm{Ca}^{2+}$ in the fusion process through a specific interaction with GATE16, a mammalian ATG8 homologue [131].

\subsection{TPC Channels in Autophagy}

The role of TPCs in autophagy has been conflicting. Pereira et al. [132] showed that in astrocytes, NAADP and TPC2 overexpression increased the levels of autophagy markers, LC3 and beclin-1, and NAADP-mediated increases in LC3II levels were reduced in cells expressing a dominant-negative TPC 2 construct. In the meantime, Leucine-rich repeat kinase 2 (LRRK2), an important regulator of autophagy involved in late-onset familial Parkinson's disease (PD) [133], activated the CaMKK $\beta$ )/AMPK pathway, which was followed by a persistent increase in autophagosome formation. These effects were mimicked by the lysosomal $\mathrm{Ca}^{2+}$-mobilizing messenger NAADP and reversed by an NAADP receptor antagonist or expression of dominant-negative receptor constructs, suggesting that TPC2-mediated lysosomal $\mathrm{Ca}^{2+}$ release may promote autophagy [134]. However, skeletal muscles from animals lacking TPC2 displayed an enhanced autophagy flux [135]. In addition, loss of TPCs did not appear to have gross defects in autophagy in the liver, heart, and macrophages [65]. There, the role of TPC2 in autophagy may be dependent on the conditions. Interestingly, Cang et al. suggested that ATP/mTOR phosphorylates and inhibits TPCs, thereby acting as a nutrient sensor to detect nutrient status in response to intracellular ATP and mTOR levels [65]. In contrast, in skeletal muscle, the loss of TPC2 leads to a reduced mTOR [135]. It seems that TPC2 and mTOR form a feedback regulatory loop in response to nutrient status.

\subsection{Other Channels in Autophagy}

Although most voltage gated $\mathrm{Ca}^{2+}$ channels (VGCCs) are found in the plasma membrane of excitable cells, P/Q-type VGCCs are recently reported to be expressed in lysosomes of both mice and fruit flies. Loss of VGCC leads to defects in autophagosome-lysosome fusion, indicating an important role of $\mathrm{Ca}^{2+}$ flux through this channel in autophagy [64].

\section{Lysosomal $\mathrm{Ca}^{2+}$, Autophagy, and Cancer}

An increasing number of tumorigenic pathways have been associated with an altered expression level or abnormal activation of $\mathrm{Ca}^{2+}$ regulatory membrane proteins including $\mathrm{Ca}^{2+}$ channels, transporters, or $\mathrm{Ca}^{2+}$-ATPases [136-141]. Abnormal autophagy has also been implicated in cancer development. It protects against the initiation of carcinogenesis, but also has a role enabling the survival of cells in solid tumors where nutrients are limited [142-146]. Given that lysosomal $\mathrm{Ca}^{2+}$ channels play an important role in autophagy, the role of lysosomal $\mathrm{Ca}^{2+}$ channels in cancer development has attracted great attention in recent years $[24,25,147-149]$. It is believed that impaired lysosomal $\mathrm{Ca}^{2+}$ signaling is a culprit in malignant tumor development [122]. Indeed, emerging evidence has demonstrated that lysosomal $\mathrm{Ca}^{2+}$ signaling underlies several cancer hallmarks involving proliferation, metastasis, and angiogenesis and contributes to multidrug resistance in cancer therapy $[122,150-160]$. Here we discuss the roles of the two major $\mathrm{Ca}^{2+}$ permeable channels, TRPMLs and TPCs, in cancer. 


\subsection{TRPMLs in Cancer}

Recently, three groups have suggested independently that TRPML1 is required for tumor progression. Jung et al. [151] showed that TRPML1 expression was significantly elevated in HRAS-positive tumors and inversely correlated with patient prognosis. TRPML1 knockdown or inhibition selectively reduced the proliferation of cancer cells that express oncogenic but not wild-type HRAS. Mechanistically, they suggested that TRPML1 promotes cancer development by mediating cholesterol de-esterification and transport to maintain oncogenic HRAS in signaling-competent nanoclusters at the plasma membrane. In the meantime, $\mathrm{Xu}$ et al. [155] reported that in triple-negative breast cancer (TNBC), the expression level of TRPML1 was upregulated, promoting tumor proliferation via activating mTORC1 pathway. This is in agreement with previous findings that $\mathrm{Ca}^{2+}$ passing through TRPML1 is required for mTORC1 activation and cell growth [22,23]. In TNBC [155], TRPML1 also promoted lysosomal exocytosis [161-164], releasing lysosomal ATP $[68,163,165]$ to the tumor microenvironment to facilitate cancer cell migration and invasion. Knockdown or inhibition of TRPML1 dampened tumor growth, cell migration, and invasion. Inversely, Kasitinon et al. [156] suggested that TRPML1 negatively regulated mTORC1 signaling to preferentially promote the survival and proliferation of melanoma cells, potentially by sustaining macropinocytosis and avoiding proteotoxic stress. Therefore, TRPML1 is necessary for cancer development by regulating multifaceted cellular signaling pathways. In line with this, TRPML1 inhibitor ML-SI1 has successfully suppressed the development of TNBC [155] and cancers bearing HRAS mutations [151]. Future studies should focus on optimizing known TRPML1 inhibitors (Table 1) and developing new drugs that specifically target on TRPML1 to treat some cancers.

Notably, the clinical course of patients with cancer is also related to the TRPML1 expression level. Elevated TRPML1 expression level is reported to associate with the poor prognosis of pancreatic ductal adenocarcinoma (PDAC) patients. Overall survival rate and recurrence-free survival are significantly lower in patients with high TRPML1 expression as compared with patients with low TRPML1 expression [166].

Although TRPML1 is often upregulated in cancer cells to promote cancer generation in glioblastoma TRPML1 agonist, MK6-83, reduce cell viability, and promote caspase-3dependent apoptosis. Blocking TRPML1 dependent $\mathrm{Ca}^{2+}$ release or silencing TRPML1 abrogated these effects. Loss or reduction of TRPML1 transcripts strongly correlates with short survival in glioblastoma patients, suggesting that the reduction of TRPML1 expression may be negatively linked to prognosis for glioblastoma patients [167]. Therefore, the role of TRPML1 in cancer development is dependent on the types of cancers.

TRPML2 has been linked to glioma, because a high level of TRPML2 was detected in glioma tissues, and because its expression level increased with pathological grades [158]. Mechanistically, TRPML2 promoted tumor cell viability by inhibiting caspase-3 activity and increased proliferation through AKT and ERK1/2 phosphorylation. Silencing and knock-down of TRPML2 reduced proliferation of tumor cells and induced apoptosis [158].

The role of TRPML3 in cancer development has not been well studied. Wu et al. [168] reported that TRPML3 level is significantly downregulated in pancreatic adenocarcinoma tissues compared with non-tumor tissues. However, in squamous cell carcinoma and hepatocellular carcinoma, TRPML3 expression level was reported to be upregulated [169]. Therefore, further studies are needed to clarify the role of TRPML3 in different cancer types.

\subsection{TPCs in Cancer}

Emerging evidence has also suggested a role of TPCs in cancer development. Early studies suggested that TPC2 expression is increased in oral squamous cell carcinoma cell lines [170]. Later studies further suggested a link between TPC2 and melanoma [171,172], bladder cancer, leukemia, hepatocellular carcinoma [173], and breast cancer [174,175]. Suppressing TPC2 by siRNA or inhibitors reduced cancer cell migration and adhesion in vitro and decreased lung metastases of cancer cells in vivo [173,176]. Mechanistically, TPC2 
may regulate autophagy [175] and $\beta 1$-integrin recycling [173] to affect cancer progression. Interestingly, growing evidence has suggested that vascular endothelial growth factor (VEGF), the angiogenic factor, plays an important role in cancer progression by regulating vascularization. By using a murine model of VEGF-secreting melanoma, application of ned-19, an NAADP inhibitor, strongly inhibits tumor vascularization, growth, and metastases. At cellular level, ned-19 inhibits cell viability, proliferation, and migration; at molecular level, ned-19 suppresses VEGFR2 expression and VEGF-mediated lysosomal $\mathrm{Ca}^{2+}$ release in melanoma cells [176]. In agreement with the role of VEGF in angiogenesis, other studies suggest that in endothelial cells, VEGF induces lysosomal $\mathrm{Ca}^{2+}$ release through NAADP/TPC2 to regulate angiogenesis $[177,178]$. Altogether, these data suggest that VEGF promotes cancer progression by activating VEGFR2/NAADP/TPC2-mediated $\mathrm{Ca}^{2+}$ signaling pathway in both tumor cells and endothelial cells.

An earlier study showed that TPC1 transcripts are significantly higher than TPC2 transcripts in the SKBR3 human breast cancer cell line, highlighting the link between TPC1 expression and tumorigenicity [62]. Indeed, a recent study has suggested that NAADP-mediated TPC1 lysosomal $\mathrm{Ca}^{2+}$ release mobilizes ER $\mathrm{Ca}^{2+}$ via IP3R, subsequently promoting the proliferation of metastatic colorectal cancer ( $\mathrm{mCRC}$ ) cells by activating ERK and the PI3K/AKT signaling pathways [179].

\section{Conclusions}

It becomes evident that the lysosome acts as an important intracellular $\mathrm{Ca}^{2+}$ store. Given that $\mathrm{Ca}^{2+}$ signaling participates in processes that are important in cancer progression, such as autophagy, cell proliferation, growth and invasiveness, the tumor microenvironment, and resistance to anticancer therapies, it is therefore not surprising that exploration of the molecular mechanism underlying lysosomal $\mathrm{Ca}^{2+}$ homeostasis could be of great help in expanding our knowledge of the role of $\mathrm{Ca}^{2+}$ homeostasis in cancer development. In line with this, emerging evidence has suggested that $\mathrm{Ca}^{2+}$ release through lysosomal ion channels, the major lysosomal $\mathrm{Ca}^{2+}$ channels TRPML1 and TPC2, has been implicated in the progression of numerous cancers by controlling the autophagy pathway. Though more studies are needed to build a clear relation between lysosomal $\mathrm{Ca}^{2+}$ and cancer development and to underpin the precise mechanisms underlying the role of lysosomal $\mathrm{Ca}^{2+}$ in different types of cancers, developing potent and specific compounds targeting TRPML1 [151,153] and TPC2 [61] could be a promising therapeutic strategy to treat some cancers.

Author Contributions: Writing-original draft preparation, Y.W.; writing-review and editing, P.H.; supervision, X.-P.D.; funding acquisition, Y.W. and X.-P.D. All authors have read and agreed to the published version of the manuscript.

Funding: This work was supported by Shanghai Municipal Health Commission Foundation grant [20204Y0379] to Y.W. and CIHR project grant [PJT-156102] to X.D.

Acknowledgments: We apologize to colleagues whose works are not cited due to space limitations.

Conflicts of Interest: The authors declare no conflict of interest.

\section{Abbreviations}

ML-SA: mucolipin synthetic agonist; ML-SI: mucolipin synthetic inhibitor; LyNa-VA: lysosomal $\mathrm{Na}^{+}$channel voltage-dependent activator; LyNA: lysosomal $\mathrm{Na}^{+}$channel agonist.

\section{References}

1. De Duve, C.; Pressman, B.C.; Gianetto, R.; Wattiaux, R.; Appelmans, F. Tissue fractionation studies. 6. Intracellular distribution patterns of enzymes in rat-liver tissue. Biochem. J. 1955, 60, 604-617. [CrossRef] [PubMed]

2. Novikoff, A.B.; Beaufay, H.; De Duve, C. Electron microscopy of lysosomerich fractions from rat liver. J. Biophys. Biochem. Cytol. 1956, 2, 179-184. [CrossRef] 
3. Sabatini, D.D.; Adesnik, M. Christian de Duve: Explorer of the cell who discovered new organelles by using a centrifuge. Proc. Natl. Acad. Sci. USA 2013, 110, 13234-13235. [CrossRef]

4. Luzio, J.P.; Hackmann, Y.; Dieckmann, N.M.G.; Griffiths, G.M. The Biogenesis of Lysosomes and Lysosome-Related Organelles. Cold Spring Harb. Perspect. Biol. 2014, 6, a016840. [CrossRef] [PubMed]

5. Chakraborty, K.; Leung, K.; Krishnan, Y. High lumenal chloride in the lysosome is critical for lysosome function. eLife 2017, 6. [CrossRef]

6. Hipolito, V.E.; Ospina-Escobar, E.; Botelho, R.J. Lysosome remodelling and adaptation during phagocyte activation. Cell. Microbiol. 2018, 20, e12824. [CrossRef]

7. Luzio, J.P.; Pryor, P.R.; Bright, N.A. Lysosomes: Fusion and function. Nat. Rev. Mol. Cell Biol. 2007, 8, 622-632. [CrossRef]

8. Settembre, C.; Fraldi, A.; Medina, D.L.; Ballabio, A. Signals from the lysosome: A control centre for cellular clearance and energy metabolism. Nat. Rev. Mol. Cell Biol. 2013, 14, 283-296. [CrossRef] [PubMed]

9. Perera, R.M.; Zoncu, R. The Lysosome as a Regulatory Hub. Annu. Rev. Cell Dev. Biol. 2016, 32, 223-253. [CrossRef] [PubMed]

10. Ruivo, R.; Anne, C.; Sagné, C.; Gasnier, B. Molecular and cellular basis of lysosomal transmembrane protein dysfunction. Biochim. Biophys. Acta BBA Bioenergy 2009, 1793, 636-649. [CrossRef]

11. Cox, T.M.; Cachón-González, M.B. The cellular pathology of lysosomal diseases. J. Pathol. 2011, 226, 241-254. [CrossRef]

12. Settembre, C.; De Cegli, R.; Mansueto, G.; Saha, P.K.; Vetrini, F.; Visvikis, O.; Huynh, T.; Carissimo, A.; Palmer, N.; Klisch, T.J.; et al. TFEB controls cellular lipid metabolism through a starvation-induced autoregulatory loop. Nat. Cell Biol. 2013, 15, 647-658. [CrossRef]

13. Settembre, C.; Di Malta, C.; Polito, V.A.; Arencibia, M.G.; Vetrini, F.; Serkan, E.; Erdin, S.U.; Huynh, T.; Medina, D.; Colella, P.; et al. TFEB Links Autophagy to Lysosomal Biogenesis. Science 2011, 332, 1429-1433. [CrossRef]

14. Zoncu, R.; Bar-Peled, L.; Efeyan, A.; Wang, S.; Sancak, Y.; Sabatini, D.M. mTORC1 Senses Lysosomal Amino Acids Through an Inside-Out Mechanism That Requires the Vacuolar H+-ATPase. Science 2011, 334, 678-683. [CrossRef] [PubMed]

15. Lim, C.-Y.; Zoncu, R. The lysosome as a command-and-control center for cellular metabolism. J. Cell Biol. 2016, $214,653-664$. [CrossRef]

16. Napolitano, G.; Ballabio, A. TFEB at a glance. J. Cell Sci. 2016, 129, 2475-2481. [CrossRef]

17. Sardiello, M.; Palmieri, M.; Di Ronza, A.; Medina, D.L.; Valenza, M.; Gennarino, V.A.; Di Malta, C.; Donaudy, F.; Embrione, V.; Polishchuk, R.S.; et al. A Gene Network Regulating Lysosomal Biogenesis and Function. Science 2009, 325, 473-477. [CrossRef] [PubMed]

18. Carroll, B.; Dunlop, E.A. The lysosome: A crucial hub for AMPK and mTORC1 signalling. Biochem. J. 2017, 474, 1453-1466. [CrossRef]

19. Palmieri, M.; Impey, S.; Kang, H.; Di Ronza, A.; Pelz, C.; Sardiello, M.; Ballabio, A. Characterization of the CLEAR network reveals an integrated control of cellular clearance pathways. Hum. Mol. Genet. 2011, 20, 3852-3866. [CrossRef] [PubMed]

20. Sardiello, M. Transcription factor EB: From master coordinator of lysosomal pathways to candidate therapeutic target in degenerative storage diseases. Ann. N. Y. Acad. Sci. 2016, 1371, 3-14. [CrossRef] [PubMed]

21. Mizushima, N. Autophagy: Process and function. Genes Dev. 2007, 21, 2861-2873. [CrossRef]

22. Sun, X.; Yang, Y.; Zhong, X.Z.; Cao, Q.; Zhu, X.-H.; Zhu, X.; Dong, X.-P. A negative feedback regulation of MTORC1 activity by the lysosomal Ca2+ channel MCOLN1 (mucolipin 1) using a CALM (calmodulin)-dependent mechanism. Autophagy 2018, 14, 38-52. [CrossRef]

23. Li, R.-J.; Xu, J.; Fu, C.; Zhang, J.; Zheng, Y.G.; Jia, H.; Liu, J.O. Regulation of mTORC1 by lysosomal calcium and calmodulin. eLife 2016, 5, e19360. [CrossRef]

24. Medina, D.L.; Ballabio, A. Lysosomal calcium regulates autophagy. Autophagy 2015, 11, 970-971. [CrossRef]

25. Medina, D.L.; Di Paola, S.; Peluso, I.; Armani, A.; De Stefani, D.; Venditti, R.; Montefusco, S.; Rosato, A.S.; Prezioso, C.; Forrester, A.; et al. Lysosomal calcium signalling regulates autophagy through calcineurin and TFEB. Nat. Cell Biol. 2015, 17, 288-299. [CrossRef]

26. Blaby-Haas, C.E.; Merchant, S.S. Lysosome-related Organelles as Mediators of Metal Homeostasis. J. Biol. Chem. 2014, 289, 28129-28136. [CrossRef] [PubMed]

27. Lloyd-Evans, E.; Platt, F.M. Lysosomal Ca2+ homeostasis: Role in pathogenesis of lysosomal storage diseases. Cell Calcium 2011, 50, 200-205. [CrossRef] [PubMed]

28. Patel, S.; Docampo, R. Acidic calcium stores open for business: Expanding the potential for intracellular Ca2+ signaling. Trends Cell Biol. 2010, 20, 277-286. [CrossRef]

29. Saftig, P.; Klumperman, J. Lysosome biogenesis and lysosomal membrane proteins: Trafficking meets function. Nat. Rev. Mol. Cell Biol. 2009, 10, 623-635. [CrossRef]

30. Lloyd-Evans, E.; Waller-Evans, H. Lysosomal Ca2+Homeostasis and Signaling in Health and Disease. Cold Spring Harb. Perspect. Biol. 2020, 12, a035311. [CrossRef] [PubMed]

31. Lee, H.C.; Aarhus, R. A Derivative of NADP Mobilizes Calcium Stores Insensitive to Inositol Trisphosphate and Cyclic ADP-ribose. J. Biol. Chem. 1995, 270, 2152-2157. [CrossRef]

32. Churchill, G.C.; Okada, Y.; Thomas, J.M.; Genazzani, A.A.; Patel, S.; Galione, A. NAADP Mobilizes Ca2+ from Reserve Granules, Lysosome-Related Organelles, in Sea Urchin Eggs. Cell 2002, 111, 703-708. [CrossRef] 
33. Christensen, K.A.; Myers, J.T.; Swanson, J.A. pH-dependent regulation of lysosomal calcium in macrophages. J. Cell Sci. 2002, 115, 599-607.

34. Lloyd-Evans, E.; Morgan, A.J.; He, X.; Smith, D.A.; Elliot-Smith, E.; Sillence, D.J.; Churchill, G.C.; Schuchman, E.H.; Galione, A.; Platt, F.M. Niemann-Pick disease type $\mathrm{C} 1$ is a sphingosine storage disease that causes deregulation of lysosomal calcium. Nat. Med. 2008, 14, 1247-1255. [CrossRef] [PubMed]

35. Ronco, V.; Potenza, D.M.; Denti, F.; Vullo, S.; Gagliano, G.; Tognolina, M.; Guerra, G.; Pinton, P.; Genazzani, A.A.; Mapelli, L.; et al A novel Ca2+-mediated cross-talk between endoplasmic reticulum and acidic organelles: Implications for NAADP-dependent Ca2+ signalling. Cell Calcium 2015, 57, 89-100. [CrossRef] [PubMed]

36. Morgan, A.J.; Platt, F.M.; Lloyd-Evans, E.; Galione, A. Molecular mechanisms of endolysosomal Ca2+ signalling in health and disease. Biochem. J. 2011, 439, 349-378. [CrossRef] [PubMed]

37. Narayanaswamy, N.; Chakraborty, K.; Saminathan, A.; Zeichner, E.; Leung, K.; Devany, J.; Krishnan, Y. A pH-correctable, DNA-based fluorescent reporter for organellar calcium. Nat. Methods 2019, 16, 95-102. [CrossRef] [PubMed]

38. Cao, Q.; Zhong, X.Z.; Zou, Y.; Murrelllagnado, R.D.; Zhu, M.X.; Dong, X.-P. Calcium release through P2X4 activates calmodulin to promote endolysosomal membrane fusion. J. Cell Biol. 2015, 209, 879-894. [CrossRef]

39. Czibener, C.; Sherer, N.M.; Becker, S.M.; Pypaert, M.; Hui, E.; Chapman, E.R.; Mothes, W.; Andrews, N.W. Ca2+ and synaptotagmin VII-dependent delivery of lysosomal membrane to nascent phagosomes. J. Cell Biol. 2006, 174, 997-1007. [CrossRef]

40. Pryor, P.R.; Mullock, B.M.; Bright, N.A.; Gray, S.R.; Luzio, J.P. The Role of Intraorganellar Ca2+In Late Endosome-Lysosome Heterotypic Fusion and in the Reformation of Lysosomes from Hybrid Organelles. J. Cell Biol. 2000, 149, 1053-1062. [CrossRef]

41. Vergarajauregui, S.; Martina, J.A.; Puertollano, R. Identification of the Penta-EF-hand Protein ALG-2 as a Ca2+-dependent Interactor of Mucolipin-1. J. Biol. Chem. 2009, 284, 36357-36366. [CrossRef]

42. Cheng, X.; Shen, D.; Samie, M.; Xu, H. Mucolipins: Intracellular TRPML1-3 channels. FEBS Lett. 2010, 584, 2013-2021. [CrossRef]

43. Xu, H.; Ren, D. Lysosomal Physiology. Annu. Rev. Physiol. 2015, 77, 57-80. [CrossRef]

44. Chen, Q.; She, J.; Zeng, W.; Guo, J.; Xu, H.; Bai, X.-C.; Jiang, Y. Structure of mammalian endolysosomal TRPML1 channel in nanodiscs. Nat. Cell Biol. 2017, 550, 415-418. [CrossRef]

45. Li, X.; Rydzewski, N.; Hider, A.; Zhang, X.; Yang, J.; Wang, W.; Gao, Q.; Cheng, X.; Xu, H. A molecular mechanism to regulate lysosome motility for lysosome positioning and tubulation. Nat. Cell Biol. 2016, 18, 404-417. [CrossRef] [PubMed]

46. Shen, D.; Wang, X.; Li, X.; Zhang, X.; Yao, Z.; Dibble, S.; Dong, X.-P.; Yu, T.; Lieberman, A.P.; Showalter, H.D.; et al. Lipid storage disorders block lysosomal trafficking by inhibiting a TRP channel and lysosomal calcium release. Nat. Commun. $2012,3,731$. [CrossRef] [PubMed]

47. Wang, W.; Gao, Q.; Yang, M.; Zhang, X.; Yu, L.; Lawas, M.; Li, X.; Bryant-Genevier, M.; Southall, N.T.; Marugan, J.; et al. Up-regulation of lysosomal TRPML1 channels is essential for lysosomal adaptation to nutrient starvation. Proc. Natl. Acad. Sci. USA 2015, 112, E1373-E1381. [CrossRef]

48. Di Paola, S.; Scotto-Rosato, A.; Medina, D.L. TRPML1: The Ca(2+)retaker of the lysosome. Cell Calcium 2018, 69, $112-121$. [CrossRef]

49. Grimm, C.; Butz, E.; Chen, C.-C.; Wahl-Schott, C.; Biel, M. From mucolipidosis type IV to Ebola: TRPML and two-pore channels at the crossroads of endo-lysosomal trafficking and disease. Cell Calcium 2017, 67, 148-155. [CrossRef] [PubMed]

50. Grimm, C.; Jörs, S.; Saldanha, S.A.; Obukhov, A.G.; Pan, B.; Oshima, K.; Cuajungco, M.P.; Chase, P.; Hodder, P.; Heller, S. Small Molecule Activators of TRPML. Chem. Biol. 2010, 17, 135-148. [CrossRef] [PubMed]

51. Zhang, X.; Cheng, X.; Yu, L.; Yang, J.; Calvo, R.; Patnaik, S.; Hu, X.; Gao, Q.; Yang, M.; Lawas, M.; et al. MCOLN1 is a ROS sensor in lysosomes that regulates autophagy. Nat. Commun. 2016, 7, 12109. [CrossRef] [PubMed]

52. Sahoo, N.; Gu, M.; Zhang, X.; Raval, N.; Yang, J.; Bekier, M.; Calvo, R.; Patnaik, S.; Wang, W.; King, G.; et al. Gastric Acid Secretion from Parietal Cells Is Mediated by a Ca 2+ Efflux Channel in the Tubulovesicle. Dev. Cell 2017, 41, 262-273. [CrossRef] [PubMed]

53. Chen, C.-C.; Keller, M.B.; Hess, M.; Schiffmann, R.; Urban, N.; Wolfgardt, A.; Schaefer, M.; Bracher, F.; Biel, M.; Wahl-Schott, C.; et al. A small molecule restores function to TRPML1 mutant isoforms responsible for mucolipidosis type IV. Nat. Commun. 2014, 5, 4681. [CrossRef]

54. Cheng, X.; Zhang, X.; Gao, Q.; Samie, M.A.; Azar, M.; Tsang, W.L.; Dong, L.; Sahoo, N.; Li, X.; Zhuo, Y.; et al. The intracellular Ca2+ channel MCOLN1 is required for sarcolemma repair to prevent muscular dystrophy. Nat. Med. 2014, 20, 1187-1192. [CrossRef]

55. Samie, M.; Wang, X.; Zhang, X.; Goschka, A.; Li, X.; Cheng, X.; Gregg, E.; Azar, M.; Zhuo, Y.; Garrity, A.G.; et al. A TRP Channel in the Lysosome Regulates Large Particle Phagocytosis via Focal Exocytosis. Dev. Cell 2013, 26, 511-524. [CrossRef]

56. Plesch, E.; Chen, C.-C.; Butz, E.; Rosato, A.S.; Krogsaeter, E.K.; Yinan, H.; Bartel, K.; Keller, M.; Robaa, D.; Teupser, D.; et al. Selective agonist of TRPML2 reveals direct role in chemokine release from innate immune cells. eLife 2018, 7. [CrossRef] [PubMed]

57. Zhang, X.; Chen, W.; Li, P.; Calvo, R.; Southall, N.; Hu, X.; Bryant-Genevier, M.; Feng, X.; Geng, Q.; Gao, C.; et al. Agonist-specific voltage-dependent gating of lysosomal two-pore Na+ channels. eLife 2019, 8. [CrossRef] [PubMed]

58. Penny, C.J.; Vassileva, K.; Jha, A.; Yuan, Y.; Chee, X.; Yates, E.; Mazzon, M.; Kilpatrick, B.S.; Muallem, S.; Marsh, M.; et al. Mining of Ebola virus entry inhibitors identifies approved drugs as two-pore channel pore blockers. Biochim. Biophys. Acta Mol. Cell Res. 2019, 1866, 1151-1161. [CrossRef]

59. Sakurai, Y.; Kolokoltsov, A.A.; Chen, C.-C.; Tidwell, M.W.; Bauta, W.E.; Klugbauer, N.; Grimm, C.; Wahl-Schott, C.; Biel, M.; Davey, R.A. Two-pore channels control Ebola virus host cell entry and are drug targets for disease treatment. Science 2015, 347, 995-998. [CrossRef] 
60. Naylor, E.; Arredouani, A.; Vasudevan, S.R.; Lewis, A.M.; Parkesh, R.; Mizote, A.; Rosen, D.; Thomas, J.M.; Izumi, M.; Ganesan, A.; et al. Identification of a chemical probe for NAADP by virtual screening. Nat. Chem. Biol. 2009, 5, 220-226. [CrossRef]

61. Gerndt, S.; Chen, C.-C.; Chao, Y.-K.; Yuan, Y.; Burgstaller, S.; Rosato, A.S.; Krogsaeter, E.; Urban, N.; Jacob, K.; Nguyen, O.N.P.; et al. Agonist-mediated switching of ion selectivity in TPC2 differentially promotes lysosomal function. eLife 2020, 9. [CrossRef] [PubMed]

62. Brailoiu, E.; Churamani, D.; Cai, X.; Schrlau, M.G.; Brailoiu, G.C.; Gao, X.; Hooper, R.; Boulware, M.J.; Dun, N.J.; Marchant, J.S.; et al. Essential requirement for two-pore channel 1 in NAADP-mediated calcium signaling. J. Cell Biol. 2009, 186, 201-209. [CrossRef] [PubMed]

63. Wang, X.; Zhang, X.; Dong, X.-P.; Samie, M.; Li, X.; Cheng, X.; Goschka, A.; Shen, D.; Zhou, Y.; Harlow, J.; et al. TPC Proteins Are Phosphoinositide- Activated Sodium-Selective Ion Channels in Endosomes and Lysosomes. Cell 2012, 151, 372-383. [CrossRef]

64. Tian, X.; Gala, U.; Zhang, Y.; Shang, W.; Jaiswal, S.N.; Di Ronza, A.; Jaiswal, M.; Yamamoto, S.; Sandoval, H.; DuRaine, L.; et al. A voltage-gated calcium channel regulates lysosomal fusion with endosomes and autophagosomes and is required for neuronal homeostasis. PLoS Biol. 2015, 13, e1002103. [CrossRef] [PubMed]

65. Cang, C.; Zhou, Y.; Navarro, B.; Seo, Y.-J.; Aranda, K.; Shi, L.; Battaglia-Hsu, S.; Nissim, I.; Clapham, D.E.; Ren, D. mTOR Regulates Lysosomal ATP-Sensitive Two-Pore Na+ Channels to Adapt to Metabolic State. Cell 2013, 152, 778-790. [CrossRef] [PubMed]

66. Ogunbayo, O.A.; Duan, J.; Xiong, J.; Wang, Q.; Feng, X.; Ma, J.; Zhu, M.X.; Evans, A.M. mTORC1 controls lysosomal Ca2+release through the two-pore channel TPC. Sci. Signal. 2018, 11, eaao5775. [CrossRef] [PubMed]

67. Li, P.; Gu, M.; Xu, H. Lysosomal Ion Channels as Decoders of Cellular Signals. Trends Biochem. Sci. 2019, 44, 110-124. [CrossRef]

68. Huang, P.; Zou, Y.; Zhong, X.Z.; Cao, Q.; Zhao, K.; Zhu, M.X.; Murrell-Lagnado, R.; Dong, X.-P. P2X4 Forms Functional ATPactivated Cation Channels on Lysosomal Membranes Regulated by Luminal pH. J. Biol. Chem. 2014, 289, 17658-17667. [CrossRef] [PubMed]

69. Shang, S.; Zhu, F.; Liu, B.; Chai, Z.; Wu, Q.; Hu, M.; Wang, Y.; Huang, R.; Zhang, X.; Wu, X.; et al. Intracellular TRPA1 mediates $\mathrm{Ca} 2+$ release from lysosomes in dorsal root ganglion neurons. J. Cell Biol. 2016, 215, 369-381. [CrossRef]

70. Lange, I.; Yamamoto, S.; Partida-Sanchez, S.; Mori, Y.; Fleig, A.; Penner, R. TRPM2 functions as a lysosomal Ca2+-release channel in beta cells. Sci. Signal. 2009, 2, ra23. [CrossRef]

71. Morgan, A.J.; Davis, L.C.; Galione, A. Imaging approaches to measuring lysosomal calcium. Methods Cell Biol. 2015, 126, 159-195. [CrossRef]

72. Dickson, E.J.; Duman, J.G.; Moody, M.W.; Chen, L.; Hille, B. Orai-STIM-mediated Ca2+ release from secretory granules revealed by a targeted Ca2+ and pH probe. Proc. Natl. Acad. Sci. USA 2012, 109, E3539-E3548. [CrossRef] [PubMed]

73. Garrity, A.G.; Wang, W.; Collier, C.M.; Levey, S.A.; Gao, Q.; Xu, H. The endoplasmic reticulum, not the pH gradient, drives calcium refilling of lysosomes. eLife 2016, 5, e15887. [CrossRef]

74. Lemons, R.; Thoene, J. Mediated calcium transport by isolated human fibroblast lysosomes. J. Biol. Chem. 1991, 266, 14378-14382. [CrossRef]

75. Phillips, M.J.; Voeltz, G.K. Structure and function of ER membrane contact sites with other organelles. Nat. Rev. Mol. Cell Biol. 2016, 17, 69-82. [CrossRef]

76. Yang, J.; Zhao, Z.; Gu, M.; Feng, X.; Xu, H. Release and uptake mechanisms of vesicular Ca2+ stores. Protein Cell 2019, 10, 8-19. [CrossRef]

77. Atakpa, P.; Thillaiappan, N.B.; Mataragka, S.; Prole, D.L.; Taylor, C.W. IP3 Receptors Preferentially Associate with ER-Lysosome Contact Sites and Selectively Deliver Ca2+ to Lysosomes. Cell Rep. 2018, 25, 3180-3193.e7. [CrossRef]

78. Eden, E.R. The formation and function of ER-endosome membrane contact sites. Biochim Biophys Acta 2016, 1861, 874-879. [CrossRef]

79. Haller, T.; Dietl, P.; Deetjen, P.; Völkl, H. The lysosomal compartment as intracellular calcium store in MDCK cells: A possible involvement in InsP3-mediated Ca2+ release. Cell Calcium 1996, 19, 157-165. [CrossRef]

80. Kilpatrick, B.S.; Eden, E.R.; Schapira, A.H.; Futter, C.E.; Patel, S. Direct mobilisation of lysosomal Ca 2+ triggers complex Ca 2+ signals. J. Cell Sci. 2013, 126, 60-66. [CrossRef]

81. Kilpatrick, B.S.; Yates, E.; Grimm, C.; Schapira, A.H.; Patel, S. Endo-lysosomal TRP mucolipin-1 channels trigger global ER Ca2+release and Ca2+influx. J. Cell Sci. 2016, 129, 3859-3867. [CrossRef]

82. Churchill, G.C.; Galione, A. NAADP induces Ca2+ oscillations via a two-pool mechanism by priming IP3- and cADPR-sensitive Ca2+ stores. EMBO J. 2001, 20, 2666-2671. [CrossRef]

83. Gerasimenko, J.V.; Charlesworth, R.M.; Sherwood, M.W.; Ferdek, P.E.; Mikoshiba, K.; Parrington, J.; Petersen, O.H.; Gerasimenko, O.V. Both RyRs and TPCs are required for NAADP-induced intracellular Ca2+ release. Cell Calcium 2015, 58, 237-245. [CrossRef] [PubMed]

84. Galione, A. NAADP Receptors. Cold Spring Harb. Perspect. Biol. 2010, 3, a004036. [CrossRef]

85. López-Sanjurjo, C.I.; Tovey, S.C.; Prole, D.L.; Taylor, C.W. Lysosomes shape Ins $(1,4,5)$ P 3 -evoked Ca $2+$ signals by selectively sequestering Ca 2+ released from the endoplasmic reticulum. J. Cell Sci. 2013, 126, 289-300. [CrossRef]

86. Morgan, A.J.; Davis, L.C.; Wagner, S.K.; Lewis, A.M.; Parrington, J.; Churchill, G.C.; Galione, A. Bidirectional Ca2+ signaling occurs between the endoplasmic reticulum and acidic organelles. J. Cell Biol. 2013, 200, 789-805. [CrossRef] 
87. Kilpatrick, B.S.; Eden, E.R.; Hockey, L.N.; Yates, E.; Futter, C.E.; Patel, S. An Endosomal NAADP-Sensitive Two-Pore Ca 2+ Channel Regulates ER-Endosome Membrane Contact Sites to Control Growth Factor Signaling. Cell Rep. 2017, 18, 1636-1645. [CrossRef]

88. Wong, Y.C.; Ysselstein, D.; Krainc, D. Mitochondria-lysosome contacts regulate mitochondrial fission via RAB7 GTP hydrolysis. Nat. Cell Biol. 2018, 554, 382-386. [CrossRef]

89. Wong, Y.C.; Kim, S.; Peng, W.; Krainc, D. Regulation and Function of Mitochondria-Lysosome Membrane Contact Sites in Cellular Homeostasis. Trends Cell Biol. 2019, 29, 500-513. [CrossRef]

90. Peng, W.; Wong, Y.C.; Krainc, D. Mitochondria-lysosome contacts regulate mitochondrial Ca(2+) dynamics via lysosomal TRPML. Proc. Natl. Acad. Sci. USA 2020, 117, 19266-19275. [CrossRef]

91. Levine, B.; Kroemer, G. Autophagy in the Pathogenesis of Disease. Cell 2008, 132, 27-42. [CrossRef] [PubMed]

92. Komatsu, M.; Waguri, S.; Chiba, T.; Murata, S.; Iwata, J.-I.; Tanida, I.; Ueno, T.; Koike, M.; Uchiyama, Y.; Kominami, E.; et al. Loss of autophagy in the central nervous system causes neurodegeneration in mice. Nature 2006, 441, 880-884. [CrossRef]

93. Hara, T.; Nakamura, K.; Matsui, M.; Yamamoto, A.; Nakahara, Y.; Suzuki-Migishima, R.; Yokoyama, M.; Mishima, K.; Saito, I.; Okano, H.; et al. Suppression of basal autophagy in neural cells causes neurodegenerative disease in mice. Nature 2006, 441, 885-889. [CrossRef]

94. Sarnat, H.B.; Roth, S.I.; Jimenez, J.F. Neonatal Myotubular Myopathy: Neuropathy and Failure of Postnatal Maturation of Fetal Muscle. Can. J. Neurol. Sci. 1981, 8, 313-320. [CrossRef] [PubMed]

95. Sawchak, J.A.; Sher, J.H.; Norman, M.G.; Kula, R.W.; Shafiq, S.A. Centronuclear myopathy heterogeneity: Distinction of clinical types by myosin isoform patterns. Neurology 1991, 41, 135. [CrossRef]

96. Mizushima, N.; Levine, B. Autophagy in mammalian development and differentiation. Nat. Cell Biol. 2010, 12, 823-830. [CrossRef]

97. Masiero, E.; Agatea, L.; Mammucari, C.; Blaauw, B.; Loro, E.; Komatsu, M.; Metzger, D.; Reggiani, C.; Schiaffino, S.; Sandri, M. Autophagy Is Required to Maintain Muscle Mass. Cell Metab. 2009, 10, 507-515. [CrossRef]

98. Raben, N.; Hill, V.; Shea, L.; Takikita, S.; Baum, R.; Mizushima, N.; Ralston, E.; Plotz, P. Suppression of autophagy in skeletal muscle uncovers the accumulation of ubiquitinated proteins and their potential role in muscle damage in Pompe disease. Hum. Mol. Genet. 2008, 17, 3897-3908. [CrossRef]

99. De Duve, C.; Wattiaux, R. Functions of Lysosomes. Annu. Rev. Physiol. 1966, 28, 435-492. [CrossRef] [PubMed]

100. Parzych, K.R.; Klionsky, D.J. An Overview of Autophagy: Morphology, Mechanism, and Regulation. Antioxid. Redox Signal. 2014, 20, 460-473. [CrossRef]

101. Li, W.-W.; Li, J.; Bao, J.-K. Microautophagy: Lesser-known self-eating. Cell. Mol. Life Sci. 2012, 69, 1125-1136. [CrossRef]

102. Neff, N.T.; Bourret, L.; Miao, P.; Dice, J.F. Degradation of proteins microinjected into IMR-90 human diploid fibroblasts. J. Cell Biol. 1981, 91, 184-194. [CrossRef]

103. Cuervo, A.M.; Dice, J.F. Age-related Decline in Chaperone-mediated Autophagy. J. Biol. Chem. 2000, 275, 31505-31513. [CrossRef]

104. Arstila, A.U.; Trump, B.F. Studies on cellular autophagocytosis. The formation of autophagic vacuoles in the liver after glucagon administration. Am. J. Pathol. 1968, 53, 687-733. [PubMed]

105. Mizushima, N.; Ohsumi, Y.; Yoshimori, T. Autophagosome Formation in Mammalian Cells. Cell Struct. Funct. 2002, 27, 421-429. [CrossRef] [PubMed]

106. Dunn, W.A. Autophagy and related mechanisms of lysosome-mediated protein degradation. Trends Cell Biol. 1994, 4, 139-143. [CrossRef]

107. Nakatogawa, H. Mechanisms governing autophagosome biogenesis. Nat. Rev. Mol. Cell Biol. 2020, 21, 439-458. [CrossRef] [PubMed]

108. Mizushima, N.; Levine, B. Autophagy in Human Diseases. N. Engl. J. Med. 2020, 383, 1564-1576. [CrossRef] [PubMed]

109. Das, G.; Shravage, B.V.; Baehrecke, E.H. Regulation and Function of Autophagy during Cell Survival and Cell Death. Cold Spring Harb. Perspect. Biol. 2012, 4, a008813. [CrossRef]

110. Wesselborg, S.; Stork, B. Autophagy signal transduction by ATG proteins: From hierarchies to networks. Cell. Mol. Life Sci. 2015, 72, 4721-4757. [CrossRef]

111. Aits, S.; Jäättelä, M. Lysosomal cell death at a glance. J. Cell Sci. 2013, 126, 1905-1912. [CrossRef] [PubMed]

112. Kim, J.; Kundu, M.; Viollet, B.; Guan, K.-L. AMPK and mTOR regulate autophagy through direct phosphorylation of Ulk. Nat. Cell Biol. 2011, 13, 132-141. [CrossRef]

113. Martina, J.A.; Chen, Y.; Gucek, M.; Puertollano, R. MTORC1 functions as a transcriptional regulator of autophagy by preventing nuclear transport of TFEB. Autophagy 2012, 8, 903-914. [CrossRef] [PubMed]

114. Wang, L.; Ye, X.; Zhao, T. The physiological roles of autophagy in the mammalian life cycle. Biol. Rev. Camb. Philos. Soc. 2019, 94, 503-516. [CrossRef]

115. Lieberman, A.P.; Puertollano, R.; Raben, N.; Slaugenhaupt, S.; Walkley, S.U.; Ballabio, A. Autophagy in lysosomal storage disorders. Autophagy 2012, 8, 719-730. [CrossRef] [PubMed]

116. Bah, A.; Vergne, I. Macrophage Autophagy and Bacterial Infections. Front. Immunol. 2017, 8, 1483. [CrossRef] [PubMed]

117. Yun, C.W.; Lee, S.H. The Roles of Autophagy in Cancer. Int. J. Mol. Sci. 2018, 19, 3466. [CrossRef]

118. Fulda, S.; Kogel, D. Cell death by autophagy: Emerging molecular mechanisms and implications for cancer therapy. Oncogene 2015, 34, 5105-5113. [CrossRef] 
119. La Rovere, R.M.; Roest, G.; Bultynck, G.; Parys, J.B. Intracellular Ca 2+ signaling and Ca 2+ microdomains in the control of cell survival, apoptosis and autophagy. Cell Calcium 2016, 60, 74-87. [CrossRef]

120. Bootman, M.D.; Chehab, T.; Bultynck, G.; Parys, J.B.; Rietdorf, K. The regulation of autophagy by calcium signals: Do we have a consensus? Cell Calcium 2018, 70, 32-46. [CrossRef]

121. Hu, Y.-X.; Han, X.-S.; Jing, Q. Ca(2+) Ion and Autophagy. Adv. Exp. Med. Biol. 2019, 1206, 151-166. [CrossRef]

122. Kondratskyi, A.; Yassine, M.; Kondratska, K.; Skryma, R.; Slomianny, C.; Prevarskaya, N. Calcium-permeable ion channels in control of autophagy and cancer. Front. Physiol. 2013, 4, 272. [CrossRef]

123. Vergarajauregui, S.; Connelly, P.S.; Daniels, M.P.; Puertollano, R. Autophagic dysfunction in mucolipidosis type IV patients. Hum. Mol. Genet. 2008, 17, 2723-2737. [CrossRef] [PubMed]

124. Curcio-Morelli, C.; Charles, F.A.; Micsenyi, M.C.; Cao, Y.; Venugopal, B.; Browning, M.F.; Dobrenis, K.; Cotman, S.L.; Walkley, S.U.; Slaugenhaupt, S.A. Macroautophagy is defective in mucolipin-1-deficient mouse neurons. Neurobiol. Dis. 2010, 40, 370-377. [CrossRef]

125. Huang, P.; Xu, M.; Wu, Y.; Syeda, A.K.R.; Dong, X.-P.; Mengnan, X.; Yi, W. Multiple facets of TRPML1 in autophagy. Cell Calcium 2020, 88, 102196. [CrossRef]

126. Scotto Rosato, A.; Montefusco, S.; Soldati, C.; Di Paola, S.; Capuozzo, A.; Monfregola, J.; Polishchuk, E.; Amabile, A.; Grimm, C.; Lombardo, A.; et al. TRPML1 links lysosomal calcium to autophagosome biogenesis through the activation of the CaMKKbeta/VPS34 pathway. Nat. Commun. 2019, 10, 5630. [CrossRef] [PubMed]

127. Sun, T.; Wang, X.; Lu, Q.; Ren, H.; Zhang, H. CUP-5, The C. elegans ortholog of the mammalian lysosomal channel protein MLN1/TRPML1, is required for proteolytic degradation in autolysosomes. Autophagy 2011, 7, 1308-1315. [CrossRef] [PubMed]

128. Yang, Y.; Xu, M.; Zhu, X.; Yao, J.; Shen, B.; Dong, X.-P. Lysosomal Ca2+ release channel TRPML1 regulates lysosome size by promoting mTORC1 activity. Eur. J. Cell Biol. 2019, 98, 116-123. [CrossRef]

129. Kim, H.J.; Soyombo, A.A.; Tjon-Kon-Sang, S.; So, I.; Muallem, S. The Ca2+Channel TRPML3 Regulates Membrane Trafficking and Autophagy. Traffic 2009, 10, 1157-1167. [CrossRef]

130. Kim, S.W.; Kim, D.H.; Park, K.S.; Kim, M.K.; Park, Y.M.; Muallem, S.; So, I.; Kim, H.J. Palmitoylation controls trafficking of the intracellular Ca2+ channel MCOLN3/TRPML3 to regulate autophagy. Autophagy 2019, 15, 327-340. [CrossRef] [PubMed]

131. Choi, S.; Kim, H.J. The Ca2+ channel TRPML3 specifically interacts with the mammalian ATG8 homologue GATE16 to regulate autophagy. Biochem. Biophys. Res. Commun. 2014, 443, 56-61. [CrossRef]

132. Pereira, G.J.S.; Hirata, H.; Fimia, G.M.; Carmo, L.G.D.; Bincoletto, C.; Han, S.W.; Stilhano, R.S.; Ureshino, R.P.; Bloor-Young, D.; Churchill, G.; et al. Nicotinic Acid Adenine Dinucleotide Phosphate (NAADP) Regulates Autophagy in Cultured Astrocytes. J. Biol. Chem. 2011, 286, 27875-27881. [CrossRef]

133. Tolosa, E.; Vila, M.; Klein, C.; Rascol, O. LRRK2 in Parkinson disease: Challenges of clinical trials. Nat. Rev. Neurol. 2020, 16, 97-107. [CrossRef]

134. Gómez-Suaga, P.; Luzón-Toro, B.; Churamani, D.; Zhang, L.; Bloor-Young, D.; Patel, S.; Woodman, P.G.; Churchill, G.C.; Hilfiker, S. Leucine-rich repeat kinase 2 regulates autophagy through a calcium-dependent pathway involving NAADP. Hum. Mol. Genet. 2011, 21, 511-525. [CrossRef]

135. Lin, P.-H.; Duann, P.; Komazaki, S.; Park, K.H.; Li, H.; Sun, M.; Sermersheim, M.; Gumpper, K.; Parrington, J.; Galione, A.; et al. Lysosomal Two-pore Channel Subtype 2 (TPC2) Regulates Skeletal Muscle Autophagic Signaling. J. Biol. Chem. 2015, 290, 3377-3389. [CrossRef] [PubMed]

136. Gkika, D.; Prevarskaya, N. TRP channels in prostate cancer: The good, the bad and the ugly? Asian J. Androl. 2011, 13, 673-676. [CrossRef]

137. Karacosta, L.G.; Foster, B.A.; Azabdaftari, G.; Feliciano, D.M.; Edelman, A.M. A Regulatory Feedback Loop Between $\mathrm{Ca} 2+/$ Calmodulin-dependent Protein Kinase Kinase 2 (CaMKK2) and the Androgen Receptor in Prostate Cancer Progression. J. Biol. Chem. 2012, 287, 24832-24843. [CrossRef]

138. Liu, L.H.; Boivin, G.P.; Prasad, V.; Periasamy, M.; Shull, G.E. Squamous Cell Tumors in Mice Heterozygous for a Null Allele of Atp2a2, Encoding the Sarco(endo)plasmic Reticulum Ca2+-ATPase Isoform 2 Ca2+Pump. J. Biol. Chem. 2001, 276, 26737-26740. [CrossRef] [PubMed]

139. Monteith, G.R.; Davis, F.M.; Roberts-Thomson, S.J. Calcium Channels and Pumps in Cancer: Changes and Consequences. J. Biol. Chem. 2012, 287, 31666-31673. [CrossRef]

140. Roderick, H.L.; Cook, S.J. Ca2+ signalling checkpoints in cancer: Remodelling Ca2+ for cancer cell proliferation and survival. Nat. Rev. Cancer 2008, 8, 361-375. [CrossRef]

141. Zhu, H.; Zhang, H.; Jin, F.; Fang, M.; Huang, M.; Yang, C.S.; Chen, T.; Fu, L.; Pan, Z. Elevated Orai1 expression mediates tumor-promoting intracellular Ca2+ oscillations in human esophageal squamous cell carcinoma. Oncotarget 2014, 5, 3455-3471. [CrossRef]

142. Galluzzi, L.; Pietrocola, F.; Pedro, J.M.B.-S.; Amaravadi, R.K.; Baehrecke, E.H.; Cecconi, F.; Codogno, P.; Debnath, J.; Gewirtz, D.A.; Karantza, V.; et al. Autophagy in malignant transformation and cancer progression. EMBO J. 2015, 34, 856-880. [CrossRef]

143. Santana-Codina, N.; Mancias, J.D.; Kimmelman, A.C. The Role of Autophagy in Cancer. Annu. Rev. Cancer Biol. 2017, 1, 19-39. [CrossRef]

144. Li, X.; He, S.; Ma, B. Autophagy and autophagy-related proteins in cancer. Mol. Cancer 2020, 19, 1-16. [CrossRef] 
145. Levy, J.M.M.; Thorburn, A. Autophagy in cancer: Moving from understanding mechanism to improving therapy responses in patients. Cell Death Differ. 2020, 27, 843-857. [CrossRef] [PubMed]

146. Kondo, Y.; Kanzawa, T.; Sawaya, R.; Kondo, S. The role of autophagy in cancer development and response to therapy. Nat. Rev. Cancer 2005, 5, 726-734. [CrossRef]

147. Towers, C.G.; Thorburn, A. Targeting the Lysosome for Cancer Therapy. Cancer Discov. 2017, 7, 1218-1220. [CrossRef]

148. Geisslinger, F.; Müller, M.; Vollmar, A.M.; Bartel, K. Targeting Lysosomes in Cancer as Promising Strategy to Overcome Chemoresistance-A Mini Review. Front. Oncol. 2020, 10, 1156. [CrossRef] [PubMed]

149. Faris, P.; Shekha, M.; Montagna, D.; Guerra, G.; Moccia, F. Endolysosomal Ca(2+) Signalling and Cancer Hallmarks: Two-Pore Channels on the Move, TRPML1 Lags Behind! Cancers 2018, 11, 27. [CrossRef]

150. Cui, C.; Merritt, R.; Fu, L.; Pan, Z. Targeting calcium signaling in cancer therapy. Acta Pharm. Sin. B 2017, 7, 3-17. [CrossRef]

151. Jung, J.; Cho, K.; Naji, A.K.; Clemons, K.N.; Wong, C.O.; Villanueva, M.; Gregory, S.; Karagas, N.E.; Tan, L.; Liang, H.; et al. HRAS-driven cancer cells are vulnerable to TRPML1 inhibition. EMBO Rep. 2019, 20, e46685. [CrossRef]

152. Lawrence, R.E.; Zoncu, R. The lysosome as a cellular centre for signalling, metabolism and quality control. Nat. Cell Biol. 2019, 21, 133-142. [CrossRef]

153. Jung, J.; Venkatachalam, K. TRPML1 and RAS-driven cancers-Exploring a link with great therapeutic potential. Channels 2019, 13, 374-381. [CrossRef]

154. Elliott, I.A.; Dann, A.M.; Xu, S.; Kim, S.S.; Abt, E.R.; Kim, W.; Poddar, S.; Moore, A.; Zhou, L.; Williams, J.L.; et al. Lysosome inhibition sensitizes pancreatic cancer to replication stress by aspartate depletion. Proc. Natl. Acad. Sci. USA 2019, 116, 6842-6847. [CrossRef] [PubMed]

155. Xu, M.; Almasi, S.; Yang, Y.; Yan, C.; Sterea, A.M.; Syeda, A.K.R.; Shen, B.; Derek, C.R.; Huang, P.; Gujar, S.; et al. The lysosomal TRPML1 channel regulates triple negative breast cancer development by promoting mTORC1 and purinergic signaling pathways. Cell Calcium 2019, 79, 80-88. [CrossRef] [PubMed]

156. Kasitinon, S.Y.; Eskiocak, U.; Martin, M.; Bezwada, D.; Khivansara, V.; Tasdogan, A.; Zhao, Z.; Mathews, T.; Aurora, A.B.; Morrison, S.J. TRPML1 Promotes Protein Homeostasis in Melanoma Cells by Negatively Regulating MAPK and mTORC1 Signaling. Cell Rep. 2019, 28, 2293-2305.e9. [CrossRef]

157. Santoni, G.; Maggi, F.; Morelli, M.B.; Santoni, M.; Marinelli, O. Transient Receptor Potential Cation Channels in Cancer Therapy. Med. Sci. 2019, 7, 108. [CrossRef]

158. Morelli, M.B.; Nabissi, M.; Amantini, C.; Tomassoni, D.; Rossi, F.; Cardinali, C.; Santoni, M.; Arcella, A.; Oliva, M.A.; Santoni, A.; et al. Overexpression of transient receptor potential mucolipin-2 ion channels in gliomas: Role in tumor growth and progression. Oncotarget 2016, 7, 43654-43668. [CrossRef] [PubMed]

159. Santoni, G.; Santoni, M.; Maggi, F.; Marinelli, O.; Morelli, M.B. Emerging Role of Mucolipins TRPML Channels in Cancer. Front. Oncol. 2020, 10, 659. [CrossRef]

160. Atakpa, P.; Van Marrewijk, L.M.; Apta-Smith, M.; Chakraborty, S.; Taylor, C.W. GPN does not release lysosomal Ca2+ but evokes $\mathrm{Ca} 2+$ release from the ER by increasing the cytosolic $\mathrm{pH}$ independently of cathepsin C. J. Cell Sci. 2019, 132, jcs223883. [CrossRef]

161. Liu, Y.; Zhou, Y.; Zhu, K. Inhibition of Glioma Cell Lysosome Exocytosis Inhibits Glioma Invasion. PLoS ONE 2012, 7, e45910. [CrossRef]

162. Takai, E.; Tsukimoto, M.; Harada, H.; Sawada, K.; Moriyama, Y.; Kojima, S. Autocrine regulation of TGF- $\beta 1$-induced cell migration by exocytosis of ATP and activation of P2 receptors in human lung cancer cells. J. Cell Sci. 2012, 125, 5051-5060. [CrossRef] [PubMed]

163. Zhang, Z.; Chen, G.; Zhou, W.; Song, A.; Xu, T.; Luo, Q.; Wang, W.; Gu, X.-S.; Duan, S. Regulated ATP release from astrocytes through lysosome exocytosis. Nat. Cell Biol. 2007, 9, 945-953. [CrossRef]

164. Machado, E.; White-Gilbertson, S.; Van De Vlekkert, D.; Janke, L.; Moshiach, S.; Campos, Y.; Finkelstein, D.; Gomero, E.; Mosca, R.; Qiu, X.; et al. Regulated lysosomal exocytosis mediates cancer progression. Sci. Adv. 2015, 1, e1500603. [CrossRef]

165. Cao, Q.; Zhao, K.; Zhong, X.Z.; Zou, Y.; Yu, H.; Huang, P.; Xu, T.-L.; Dong, X.-P. SLC17A9 Protein Functions as a Lysosomal ATP Transporter and Regulates Cell Viability. J. Biol. Chem. 2014, 289, 23189-23199. [CrossRef]

166. Hu, Z.-D.; Yan, J.; Cao, K.-Y.; Yin, Z.-Q.; Xin, W.-W.; Zhang, M.-F. MCOLN1 Promotes Proliferation and Predicts Poor Survival of Patients with Pancreatic Ductal Adenocarcinoma. Dis. Markers 2019, 2019, 9436047-9. [CrossRef]

167. Morelli, M.B.; Amantini, C.; Tomassoni, D.; Nabissi, M.; Arcella, A.; Santoni, G. Transient Receptor Potential Mucolipin-1 Channels in Glioblastoma: Role in Patient's Survival. Cancers 2019, 11, 525. [CrossRef]

168. Wu, M.; Li, X.; Zhang, T.; Liu, Z.; Zhao, Y. Identification of a Nine-Gene Signature and Establishment of a Prognostic Nomogram Predicting Overall Survival of Pancreatic Cancer. Front. Oncol. 2019, 9, 996. [CrossRef]

169. Papatheodorou, I.; Fonseca, N.A.; Keays, M.; Tang, Y.A.; Barrera, E.; Bazant, W.; Burke, M.; Füllgrabe, A.; Fuentes, A.M.-P.; George, N.; et al. Expression Atlas: Gene and protein expression across multiple studies and organisms. Nucleic Acids Res. 2018, 46, D246-D251. [CrossRef]

170. Huang, X.; Godfrey, T.E.; Gooding, W.E.; Mccarty, K.S.; Gollin, S.M. Comprehensive genome and transcriptome analysis of the 11q13 amplicon in human oral cancer and synteny to the 7F5 amplicon in murine oral carcinoma. Genes Chromosom. Cancer 2006, 45, 1058-1069. [CrossRef] 
171. Kocarnik, J.M.; Park, S.L.; Han, J.; Dumitrescu, L.; Cheng, I.; Wilkens, L.R.; Schumacher, F.R.; Kolonel, L.; Carlson, C.S.; Crawford, D.C.; et al. Pleiotropic and Sex-Specific Effects of Cancer GWAS SNPs on Melanoma Risk in the Population Architecture Using Genomics and Epidemiology (PAGE) Study. PLoS ONE 2015, 10, e0120491. [CrossRef]

172. Kosiniak-Kamysz, A.; Marczakiewicz-Lustig, A.; Marcińska, M.; Skowron, M.; Wojas-Pelc, A.; Pośpiech, E.; Branicki, W. Increased risk of developing cutaneous malignant melanoma is associated with variation in pigmentation genes and VDR, and may involve epistatic effects. Melanoma Res. 2014, 24, 388-396. [CrossRef]

173. Nguyen, O.N.P.; Grimm, C.; Schneider, L.S.; Chao, Y.-K.; Atzberger, C.; Bartel, K.; Watermann, A.; Ulrich, M.; Mayr, D.; WahlSchott, C.; et al. Two-Pore Channel Function Is Crucial for the Migration of Invasive Cancer Cells. Cancer Res. 2017, 77, 1427-1438. [CrossRef]

174. Jahidin, A.H.; Stewart, T.A.; Thompson, E.W.; Roberts-Thomson, S.J.; Monteith, G.R. Differential effects of two-pore channel protein 1 and 2 silencing in MDA-MB-468 breast cancer cells. Biochem. Biophys. Res. Commun. 2016, 477, 731-736. [CrossRef]

175. Sun, W.; Yue, J. TPC2 mediates autophagy progression and extracellular vesicle secretion in cancer cells. Exp. Cell Res. 2018, 370, 478-489. [CrossRef] [PubMed]

176. Favia, A.; Pafumi, I.; Desideri, M.; Padula, F.; Montesano, C.; Passeri, D.; Nicoletti, C.; Orlandi, A.; Del Bufalo, D.; Sergi, M.; et al. NAADP-Dependent Ca2+ Signaling Controls Melanoma Progression, Metastatic Dissemination and Neoangiogenesis. Sci. Rep. 2016, 6, 18925. [CrossRef]

177. Favia, A.; Desideri, M.; Gambara, G.; D’Alessio, A.; Ruas, M.; Esposito, B.; Del Bufalo, D.; Parrington, J.; Ziparo, E.; Palombi, F.; et al. VEGF-induced neoangiogenesis is mediated by NAADP and two-pore channel-2-dependent Ca2+ signaling. Proc. Natl. Acad. Sci. USA 2014, 111, E4706-E4715. [CrossRef]

178. Pafumi, I.; Festa, M.; Papacci, F.; Lagostena, L.; Giunta, C.; Gutla, V.; Cornara, L.; Favia, A.; Palombi, F.; Gambale, F.; et al. Naringenin Impairs Two-Pore Channel 2 Activity and Inhibits VEGF-Induced Angiogenesis. Sci. Rep. 2017, 7, 1-11. [CrossRef]

179. Faris, P.; Pellavio, G.; Ferulli, F.; Di Nezza, F.; Shekha, M.; Lim, D.; Maestri, M.; Guerra, G.; Ambrosone, L.; Pedrazzoli, P.; et al. Nicotinic Acid Adenine Dinucleotide Phosphate (NAADP) Induces Intracellular $\mathrm{Ca}(2+)$ Release through the Two-Pore Channel TPC1 in Metastatic Colorectal Cancer Cells. Cancers 2019, 11, 542. [CrossRef] 